\title{
Using Hydrogeomorphic Criteria to Classify Wetlands on Mt. Desert Island, Maine-Approach, Classification System, and Examples
}

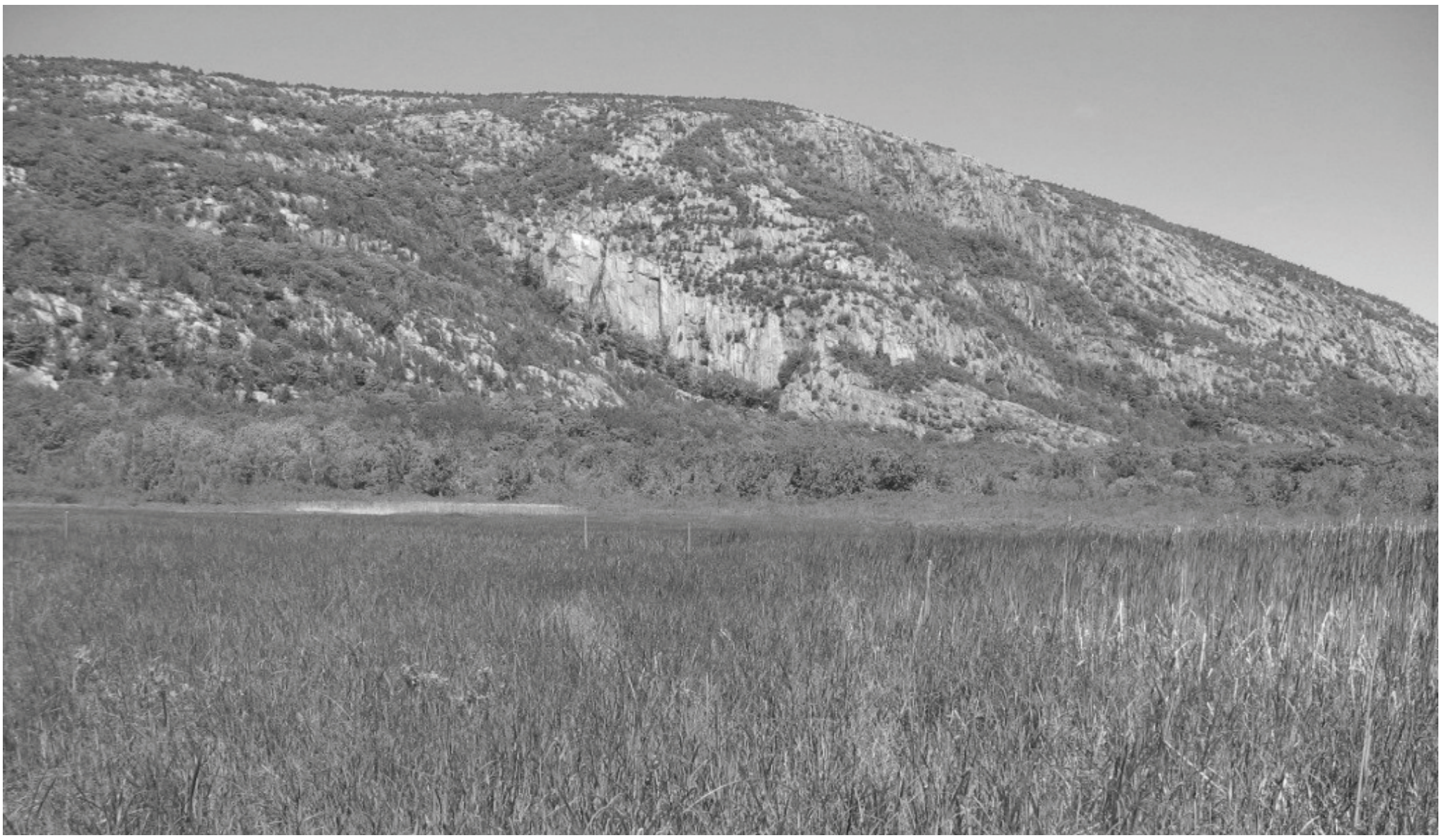

Scientific Investigations Report 2005-5244

U.S. Department of the Interior

U.S. Geological Survey

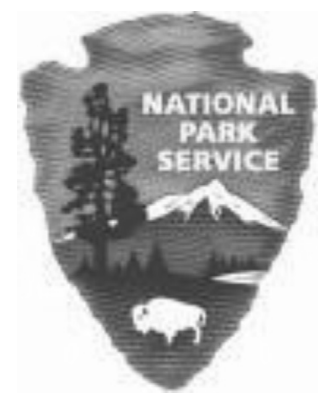


Cover Photograph:Wetland at the base of Champlain Mountain, Bar Harbor, Maine, by Hilary A. Neckles. 


\section{Using Hydrogeomorphic Criteria to Classify Wetlands on Mt. Desert Island, Maine- Approach, Classification System, and Examples}

By Martha G. Nielsen, Glenn R. Guntenspergen, and Hilary A. Neckles

In cooperation with the National Park Service

Scientific Investigations Report 2005-5244 


\section{U.S. Department of the Interior DIRK KEMPTHORNE, Secretary \\ U.S. Geological Survey \\ P. Patrick Leahy, Acting Director}

U.S. Geological Survey, Reston, Virginia: 2006

Second edition: July 2006

For product and ordering information:

World Wide Web: http://www.usgs.gov/pubprod

Telephone: 1-888-ASK-USGS

For more information on the USGS--the Federal source for science about the Earth, its natural and living resources, natural hazards, and the environment:

World Wide Web: http://www.usgs.gov

Telephone: 1-888-ASK-USGS

Any use of trade, product, or firm names is for descriptive purposes only and does not imply endorsement by the U.S. Government.

Although this report is in the public domain, permission must be secured from the individual copyright owners to reproduce any copyrighted materials contained within this report.

Suggested citation:

Nielsen, M.G., Guntenspergen, G.R., and Neckles, H.A., 2006, Using hydrogeomorphic criteria to classify wetlands on Mt. Desert Island, Maine-approach, classification system, and examples: U.S. Geological Survey Scientific Investigations Report 2005-5244, 27 p. 


\section{Contents}

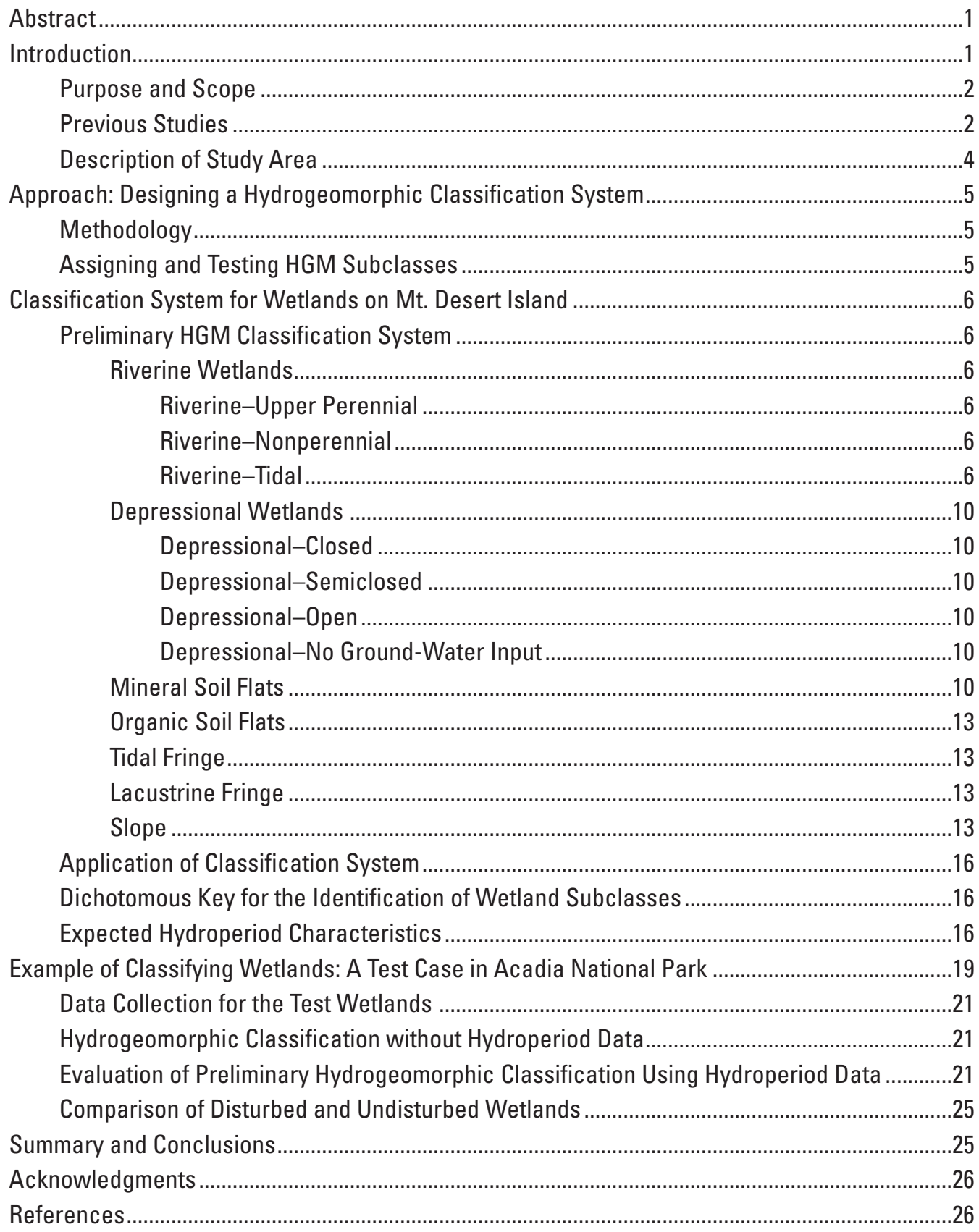

\section{Figures}

1. Map showing extent of shallow water, nonmarine wetlands on Mt. Desert Island,

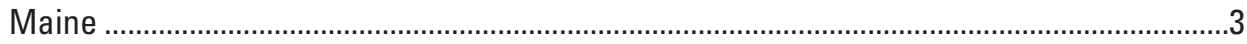

2. Index map showing location of example wetland figures, Mt. Desert Island, Maine ...........8 
3. Map showing Riverine-Upper Perennial example: wetlands adjacent to Old Mill Brook, Bar Harbor, Maine

4. Map showing Riverine-Nonperennial example: wetland east of Round Pond and north of Long Pond, Mount Desert, Maine...

5. Map showing Depressional-Closed example: wetland north of The Beehive, Bar Harbor, Maine .

6. Map showing Depressional-Semiclosed example: wetland west of Norway Drive, Bar Harbor, Maine.

7. Map showing Depressional-Open example: wetland west of Eagle Lake, Bar Harbor, Maine.

8. Map showing Mineral Soil Flat example: wetland west of Route 102/198 near Jones Marsh, Bar Harbor, Maine

9. Map showing Organic Soil Flat example: Big Heath wetland, southeast of Bass Harbor, Southwest Harbor, Maine.

10. Map showing Tidal Fringe example: wetland at the mouth of Northeast Creek, Bar Harbor, Maine.

11. Map showing Lacustrine Fringe example: wetlands near Ripple Pond, west of Somes Sound, Mount Desert, Maine...

12. Schematic cross section of one example of slope wetland formation

13. Map showing Slope example: wetlands in Marshall, Heath, and Lurvey Brooks watersheds, Mount Desert and Tremont, Maine.

14. Map showing locations of wetlands greater than 2 hectares and wetland sites for test classificaiton, Mt. Desert Island, Maine.

15. Map showing example hydroperiod data for selected wetland subclasses: A. closed depressional wetland, B. semiclosed depressional wetland, C. upper perennial riverine wetland, and D. precipitation record for wetland data-collection period

\section{Tables}

1. Hydrogeomorphic classification for Mt. Desert Island, Maine. .........................................

2. Hydrogeomorphic Classification Key for Mt. Desert Island, Maine. .................................17

3. Expected hydroperiod characteristics for hydrogeomorphic subclasses, Mt. Desert Island, Maine.

4. Classification of example wetlands using dichotomous key for wetland classification, Mt. Desert Island, Maine. 


\section{Conversion Factors and Datum}

\begin{tabular}{lll}
\multicolumn{1}{c}{ SI to Inch/Pound } & & \\
\hline Multiply & By & To obtain \\
\hline & Length & \\
\hline centimeter $(\mathrm{cm})$ & 0.3937 & inch (in.) \\
millimeter $(\mathrm{mm})$ & 0.0394 & inch (in.) \\
meter $(\mathrm{m})$ & 3.281 & foot (ft) \\
kilometer $(\mathrm{km})$ & 0.6214 & mile (mi) \\
\hline & Area & \\
\hline hectare $(\mathrm{ha})$ & 2.471 & acre \\
square $\mathrm{km}\left(\mathrm{km}^{2}\right)$ & 0.3861 & square mi $\left(\mathrm{mi}^{2}\right)$ \\
\hline
\end{tabular}

Salinity is measured in parts per thousand (ppt).

Vertical coordinate information is referenced to the North American Vertical Datum of 1988 (NAVD 88).

Horizontal coordinate information is referenced to the North American Datum of 1983 (NAD 83). 



\title{
Using Hydrogeomorphic Criteria to Classify Wetlands on Mt. Desert Island, Maine-Approach, Classification System, and Examples
}

\author{
By Martha G. Nielsen, Glenn R. Guntenspergen, and Hilary A. Neckles
}

\section{Abstract}

A wetland classification system was designed for Mt. Desert Island, Maine, to help categorize the large number of wetlands (over 1,200 mapped units) as an aid to understanding their hydrologic functions. The classification system, developed by the U.S. Geological Survey (USGS), in cooperation with the National Park Service, uses a modified hydrogeomorphic (HGM) approach, and assigns categories based on position in the landscape, soils and surficial geologic setting, and source of water. A dichotomous key was developed to determine a preliminary HGM classification of wetlands on the island. This key is designed for use with USGS topographic maps and 1:24,000 geographic information system (GIS) coverages as an aid to the classification, but may also be used with field data.

Hydrologic data collected from a wetland monitoring study were used to determine whether the preliminary classification of individual wetlands using the HGM approach yielded classes that were consistent with actual hydroperiod data. Preliminary HGM classifications of the 20 wetlands in the monitoring study were consistent with the field hydroperiod data. The modified HGM classification approach appears robust, although the method apparently works somewhat better with undisturbed wetlands than with disturbed wetlands. This wetland classification system could be applied to other hydrogeologically similar areas of northern New England.

\section{Introduction}

Tools are needed to quickly evaluate wetland function, benefits, and integrity. Many evaluation methods have been developed for site-specific studies of wetlands (for example, Adamus and others, 1987; Rheinhardt and others, 1997), but the time needed to conduct these evaluations makes their use difficult on enough wetlands to answer basic questions about the distribution of wetland type or functions in any region. The classification of a population of wetlands using a more rapid method would improve the ability to assess wetland integrity and functions on a regional scale, and provide information needed for the protection and maintenance of the benefits wetlands provide.

One tool that has been developed to help understand wetland function is the hydrogeomorphic (HGM) approach (Brinson, 1993). Wetland hydrology, including water source and hydrodynamics, is typically considered the single most important factor controlling wetland ecosystem processes (Mitsch and Gosselink, 2000). The HGM approach is based on classification (hydrological segregation) that results in an organization of wetlands according to different potential functions and benefits. Traditionally, the HGM approach is conducted in a wetlands permitting setting, by comparing a particular wetland to a set of defined reference wetlands that span a functional integrity spectrum, to determine the degree to which the wetland in question functions as a degraded or an undegraded example of wetlands with similar hydrology. This is a time- and resource-consuming process that cannot easily be replicated on every wetland within a large region, such as the northeastern United State (U.S.), where wetlands cover over 20 percent of the landscape in some areas (Fretwell and others, 1996). Use of the HGM concept in an approach that can be applied to all the wetlands in a smaller region in a relatively short amount of time could significantly improve the ability to assess the hydrologic function of a population of wetlands. This in turn would assist resource managers in the evaluation, monitoring, and status reporting for the management and protection of these wetland resources.

In 2003, the U.S. Geological Survey (USGS) began a cooperative study with the National Park Service, Water Resources Division, to design and evaluate a method of applying the principles of HGM classification to the wetlands of Acadia National Park (ANP) and Mt. Desert Island (MDI), Maine, using readily available map-scale data, rather than labor-intensive site-specific data. Mt. Desert Island contains a high diversity of wetland types and geomorphic settings, and therefore is a good test area to develop a hydrologically based classification system. 


\section{Using Hydrogeomorphic Criteria to Classify Wetlands on Mt. Desert Island, Maine-Approach, Classification System, and Examples}

\section{Purpose and Scope}

This report presents an HGM wetland classification for MDI, Maine, and a method for applying the classification to wetlands larger than 0.4 ha ( 1 acre) using map-scale data and a geographic information system (GIS), without the need for new hydrologic data. To check the validity of this approach, a test was performed on 20 wetlands on the island that had hydroperiod data collected over two field seasons, in 2000 and 2001. The HGM classification system presented in this report is considered preliminary and subject to revision. It does not take the place of localized, field-based studies of wetlands, which can provide detailed information that a map-scale analysis cannot be expected to replace.

\section{Previous Studies}

Wetlands can be grouped according to many classification systems. The wetlands of MDI and ANP (fig. 1) have been classified by Calhoun and others (1994) for the National Wetland Inventory (NWI) using the system of Cowardin and others (1979), which is based on geologic factors, broad vegetation types, and to a lesser extent, hydrology. The most recent classification for wetlands on MDI was completed in 1992 (Calhoun and others, 1994). Wetlands greater than 0.4 ha (1 acre) were mapped for that classification. Wetland classes are delineated on National Wetland Inventory (NWI) maps (U.S. Fish and Wildlife Service, 1998), and the Cowardin classification system provides the basic mapping units. The NWI maps are available digitally as GIS coverages from several public sources (for example, the Maine Office of GIS, http://apollo.ogis.state.me.us/catalog/. The NWI classification and delineation provide the geographic coverage of the wetlands shown in figure 1. A recent (2003) vegetation analysis of ANP and MDI (interpreted from 1997 photography) conducted by the National Park Service also delineated wetlands based on vegetation patterns (Lubinski and others, 2003).

The Cowardin classification system (Cowardin and others, 1979) is based on a hierarchical approach that groups wetlands with similar geomorphic and hydrologic factors. Broad generic vegetation descriptors are used at the class level. Less emphasis is paid to the sources of water maintaining the wetland ecosystem's function in the landscape. Understanding the sources of water for the wetland is critical for being able to identify factors that contribute to the degree of water saturation in the wetland. The degree of water saturation in turn strongly influences the vegetative composition and ecological function of the wetland. As Calhoun and others (1994) point out, "The nature of the wetland community, be it microbial, invertebrate, vertebrate, or plant, reflects the relationship of water with the landscape - its topography, geology, land-use history, and soils." It is not only the relation of water with the wetland ecosystem that is important, but the context of the wetland in relation to the larger landscape that determines many of the wetland functions that are valued by society. If the sources or amounts of water entering the wetland change, a shift in wetland function and (or) integrity of the wetland can be expected, especially if the hydrologic change is perpetuated over several years. By identifying the primary sources of water to wetlands, HGM classification leads to more informed decisions about threats to wetland ecological function and integrity.

Calhoun and others (1994) provide a thorough overview of the hydrology and geologic history of wetlands on MDI. Hydrologic processes and landscape position of the island's nontidal freshwater wetlands are discussed in relation to Novitski's (1982) classification of Wisconsin wetlands, which includes surface-water-depression, surface-waterslope, ground-water-depression, and ground-water-slope wetlands. However, in the NWI delineation of the wetlands of MDI using the Cowardin system, most of this hydrologic information is not included because Cowardin's hydrologic variables for freshwater wetlands are quite generalized. Most of the nontidal freshwater wetlands on MDI (not counting the many large deepwater lakes) are classified in the palustrine hydrologic system and their sources of water are not further identified.

A wetland classification system based on hydrogeological variables for New England was proposed by O'Brien and Motts (1980). Their detailed system incorporated geologic, hydrologic, and topographic factors, and stressed the importance of the overall interaction of the wetland with the landscape in its role in the hydrology of an area. Proposed as a tool for decision-making on water-supply issues, this system has not been widely utilized. Another system for segregating wetlands based on hydrologic indices was developed by Lent and others (1997) for wetlands with known water budgets. Their hydrologic indices categorized wetlands by dominant source of water (ground water, surface water, or precipitation) and by the dominant outputs of water (evapotranspiration, surface water, or ground water).

The U.S. Fish and Wildlife Service (USFWS) has developed a new classification system loosely organized around HGM principles (Tiner, 2002). This classification system, called "Landscape-Level Wetland Assessment," is intended to provide an additional layer of information to existing NWI maps. This system identifies landscape position, water-flow regimes, and interactions with other water bodies for each classified wetland. In terms of water flow, it is much more detailed than traditional HGM classification.

HGM classification has been used as a convenient way to organize groups of wetlands based on three fundamental factors that influence how wetlands function: position in the landscape, dominant source of water, and hydrodynamics (flow and fluctuations in water levels within the wetland over time) (Brinson, 1993; Cole and others, 1997; Shaffer and others, 1999). In other parts of the northeastern United States, HGM classes have been useful for characterizing 


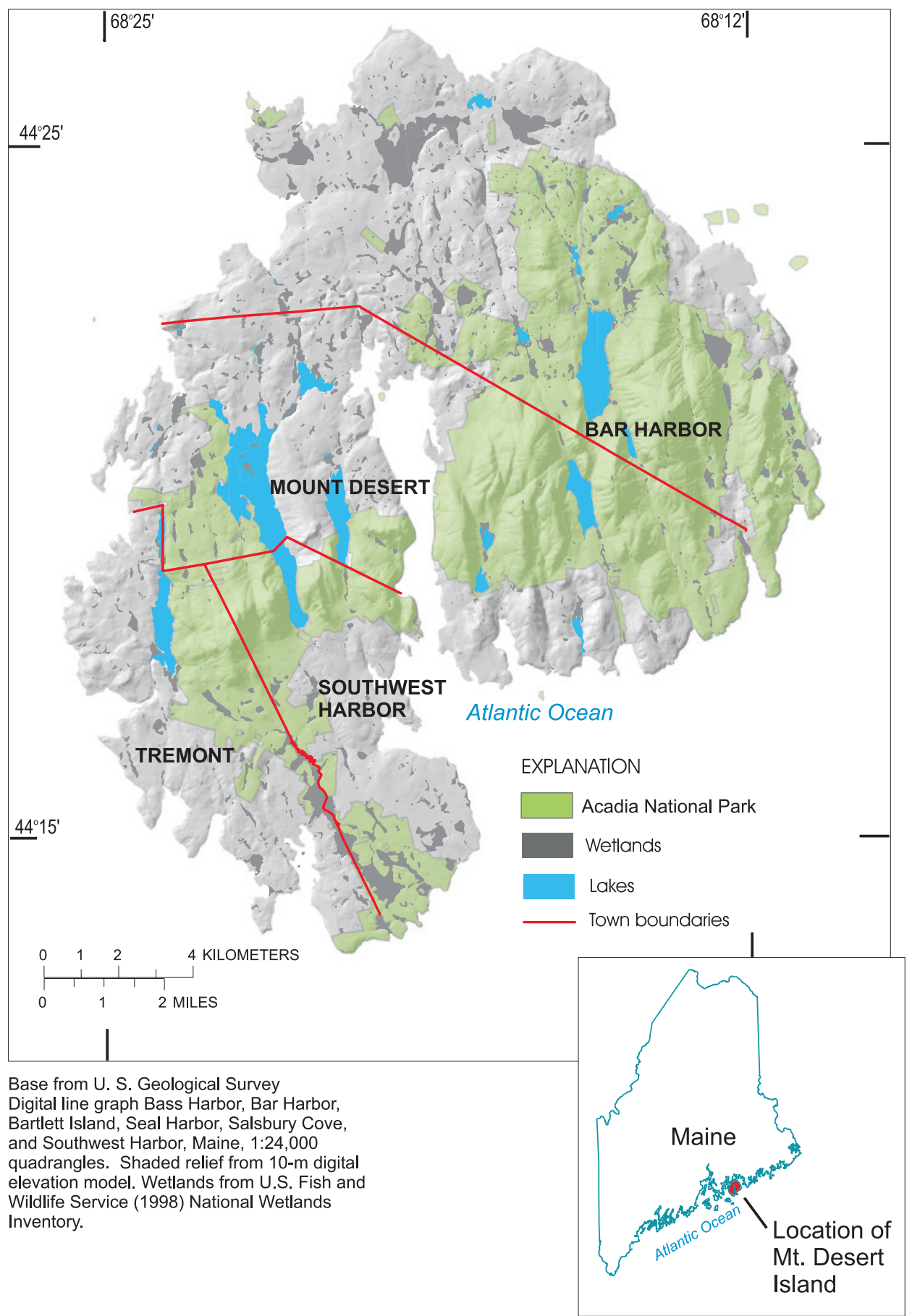

Figure 1. Extent of shallow water, nonmarine wetlands on Mt. Desert Island, Maine. 
Using Hydrogeomorphic Criteria to Classify Wetlands on Mt. Desert Island, Maine—Approach, Classification System, and Examples

wetland hydrology and have captured ecological differences among wetlands that other classifications have missed (Cole and others, 1997). To date (2006), no HGM classification system for wetlands has been published for Maine or northern New England.

Although initially designed for the U.S. Army Corps of Engineers for use in wetlands permitting, the concept of HGM classification can be applied to other uses. The traditional HGM evaluation approach requires detailed surveying of reference wetlands that span the functional capacity from pristine to highly degraded wetlands in each category. Thus, a wetland can be evaluated with respect to these reference wetlands to determine how well it functions compared to how well it might function under a predetermined reference standard (Smith and others, 1995). Although this level of detailed assessment could provide useful site-specific data on wetland hydrologic functions and values, such an investigation could be costly. A simplified version of the HGM approach also could be of great use to the National Park Service to categorize and evaluate a large number of wetlands in a short period of time. The classification presented in this report is intended to determine the most probable source of water for the wetlands, so that likely hydrologic threats to those wetlands can be identified.

The HGM approach first identifies classes of wetlands to partition the natural variation that occurs among wetlands into less variable classes. This stratification into classes recognizes that wetland functions are constrained by climate, soils, hydrology, and landscape position. Wetland function refers to the characteristic set of activities that take place in wetland ecosystems, and may range from the small spatial scales (nitrogen and nutrient cycling on a plot level) to large scales (maintaining ecological integrity in the area as a whole). Wetlands do not all perform the same functions (Smith and others, 1995). Slope wetlands, for example, do not absorb and filter floodwaters as do many riverine wetlands. The three basic factors used in HGM classification (geomorphic setting, water source, and wetland hydrodynamics) each contribute to how wetlands function in the landscape. Geomorphic setting encompasses the geologic/geomorphic evolution of the wetland and its topographic position in the landscape. Water source refers to the immediate, proximal sources of water to the wetland. Hydrodynamics are usually also included in HGM classification, and refer to the direction and frequency of water movement in and out of the wetland (Smith and others, 1995). In this HGM classification, typical hydrodynamics are described for each combination of geomorphic setting/water source identified in the classification.

\section{Description of Study Area}

MDI, with an area of $285 \mathrm{~km}^{2}\left(110 \mathrm{mi}^{2}\right)$, is the largest island on the Atlantic Coast of the United States north of Cape Cod, Massachusetts (fig. 1). Its topography ranges from gently rolling hills with slopes of around 5 percent to mountains with slopes greater than 60 percent. Rainfall is about $145 \mathrm{~cm} / \mathrm{yr}$ (National Oceanic and Atmospheric Administration, 2002), which is about $20 \mathrm{~cm}$ more than other coastal areas in Maine. ANP covers more than 50 percent of the island. The island is divided into four municipalities (the towns of Bar Harbor, Mount Desert, Southwest Harbor, and Tremont) (fig. 1) with a total year-round population of 8,770 in 2000 (U. S. Bureau of the Census, 2001). Summertime population is much higher; ANP receives approximately 2.5 million visitors per year (David Manski, Acadia National Park, Natural Resources Manager, oral commun., 2001).

Vegetation patterns for the island were determined in a survey of low-altitude infrared aerial photos taken in May 1997 (Lubinski and others, 2003). Wetlands cover 6 to 10 percent of the island (depending on which data source is used), and 11 percent of ANP (including areas of ANP not on Mt. Desert Island) (Calhoun and others, 1994). Of these, 32 percent are palustrine freshwater wetlands (nonlacustrine, nonmarine wetlands). More than 75 percent of the island is forested.

The bedrock geology of Mt. Desert Island consists primarily of granitic intrusions in the central area of the island, surrounded by a zone of contact metamorphism. Beyond this zone, which extends to the ocean on the northeast and southeast, are a group of metamorphosed layered volcanic rocks to the south (including some interbedded siltstones and slates); a gabbro-diorite band to the northwest and west; limited areas of siltstones and sandstones on the north and northeast side of the island; and a highly deformed schist on the north and west sides of the island (Gilman and others, 1988). The fractures, which allow limited amounts of ground water to accumulate and flow in the bedrock, provide water to many wetlands in low-lying areas of the island.

Discontinuous layers of glacial and postglacial sediments overlie the bedrock. Most of the higher mountains as well as many areas at lower elevations are mapped as bare bedrock (Gilman and others, 1988). The glacial sediments covering the rest of the island are mostly till and fine-grained marine sediments. Small patches of coarse-grained marine deposits and glacial delta deposits are scattered primarily on the southwestern part of the island. The only named surficial geological unit is called the Presumpscot Formation, and is a silt and clay layer of variable thickness and extent that was deposited in seawater during and after glacial retreat when sea level was between 100-120 m higher than it is today (Smith, 1985; Lowell, 1989). This unit, which is discontinuous across the island, acts as a barrier to water flow because of its clayey composition. On hilltops, it acts to inhibit recharge to the fractured bedrock and in low areas acts to inhibit discharge of ground water from the bedrock.

Wetlands across the island have developed anywhere that water can accumulate and drain slowly, which may be directly over poorly fractured bedrock, till, or Presumpscot Formation silts and clays. 


\section{Approach: Designing a Hydrogeomorphic Classification System}

The HGM classification system for Mt. Desert Island was designed using a framework modified from Brinson (1993). The important variables for HGM classification used in this study are (1) position in the landscape (hilltop, slope, valley bottom, and coastline) and (2) dominant source of water (ground water, stream, lake/pond, precipitation, overland flow, or estuary). The position of a wetland in the landscape partly determines its dominant source of water, as wetlands in defined landscape positions can obtain water only from certain sources. In other words, some landscape positions, by definition, eliminate certain water sources. Surficial geology and soils data also are used in this study to help infer water source. The primary goal of this effort is to create a classification system that can be used to efficiently assign a preliminary HGM subclass to many wetlands in a short amount of time. The classification system uses environmental data layers organized in a GIS as much as possible, and does not rely on the collection of field data.

The basic mapping units in this study are the estuarine and palustrine wetland (forested and non-forested) system classes delineated on the NWI maps. The Palustrine System includes all nontidal wetlands (with water depths of $2 \mathrm{~m}$ or less) dominated by trees, shrubs, emergent vegetation, mosses or lichens, and all such wetlands that occur in tidal areas where salinity due to ocean-derived salts is below $0.5 \mathrm{ppt}$. Estuarine wetlands are tidal wetlands with low energy and variable salinity, influenced and often semienclosed by land. These two categories together constitute the set of wetlands of most interest to the National Park Service.

\section{Methodology}

Smith and others (1995) published the basic framework for applying the principles of HGM in the United States. They also listed and defined the major HGM classes of wetlands found in the United States. Using the example of Cole and others (1997) in central Pennsylvania, the major classes described in Smith and others (1995) that occur on Mt. Desert Island were used as the framework to build upon in designing the HGM classification for this study area. Definitions for the classes and subclasses presented below largely follow Smith and others (1995), with additional detail added to enhance the utility of the definitions to the geomorphology and hydrology of Mt. Desert Island and elsewhere along the northern New England coastline. The major HGM classes described in Smith and others (1995) that apply to Mt. Desert Island include Lacustrine, Riverine, Tidal, Depressional, and Soil Flat. These classes were subdivided based on conditions found in the study area, also following Smith and others (1995) where possible. Hydrodynamic information (fluctuations of water levels over the growing season) is treated differently in this study than in typical HGM studies, and is described in a later section.

Because the eventual goal of this study is to use GIS to assist in classifying wetlands on Mt. Desert Island and similar areas, a concerted effort was made to make the subclasses as distinct from each other as possible using data from available GIS data layers. The scale of the GIS coverages available for this area generally is limited to the 7.5-minute USGS topographic quadrangles, so the HGM subclasses were designed to be determined using data at that scale. Several of the major determining factors for the HGM subclasses, such as slope or position of streams, can be read directly off the 7.5-minute topographic maps. Two other factors required for this classification, surficial geology and soils, can be determined by examining published maps, available as GIS coverages, at similar scales.

The soils data needed for the HGM classification include a description of the soil in wetland as mineral or organic soil. The surficial geology data used in the study are the geographic extent of the silt and clay deposit known as the Presumpscot Formation (Smith, 1985, Lowell, 1989). Because of its low hydraulic conductivity, the Presumpscot Formation inhibits downward or upward movement of water; where it forms a semicontinuous blanket, it is likely to effectively separate wetlands above it from the ground-water system below. This variable is not a specific part of the HGM classification, but is needed to assess potential sources of water for a particular wetland.

This method is designed to work best in hydrologically undisturbed wetlands, although information on known disturbances can be used to assist the classification or be used as a modifier after preliminary classification. Some examples of hydrologic disturbances that might affect the accuracy of the preliminary classification include beaver activity, flow restriction or constriction, ditching or other artificial draining, and excavation. Determining the presence of these disturbances in or near any classified wetland would be important to determine a final HGM classification.

\section{Assigning and Testing HGM Subclasses}

The HGM classification presented here is designed to result in a preliminary classification of wetlands on Mt. Desert Island without the need for hydrodynamic field data. To evaluate whether the concept of conducting an HGM classification without field data is valid, a test was performed on 20 wetlands on the island for which water-level data are available. Before viewing any water-level data, each of the wetlands was assigned a preliminary HGM subclass based on variables available through GIS coverages and topographic maps. None of the wetlands were visited for this classification. After the preliminary HGM subclass was assigned, the field data were examined in detail to determine the appropriateness of the preliminary assignment. 


\section{Classification System for Wetlands on Mt. Desert Island}

Results of this study are presented in this section, including the HGM classification system, a dichotomous key for assigning subclasses, and an explanation of how hydrodynamic data can be used in the classification process. The HGM classification system is considered preliminary because it was derived based on available map data, and may be revised once more specific data are collected on water budgets for the wetlands of Mt. Desert Island. Definitions for subclasses may be changed, and additional subclasses that were not considered for this study may be added in the future.

\section{Preliminary HGM Classification System}

The preliminary HGM classification system for Mt. Desert Island is shown in table 1. Details of each hydrogeomorphic subclass are explained below, and an index map showing the locations of example wetlands for each subclass is shown in figure 2 .

\section{Riverine Wetlands}

Riverine wetlands on Mt. Desert Island are found in riparian corridors associated with small first- and secondorder streams (higher-order streams do not exist on the island). The streams may be perennial, intermittent, or tidal. Water sources for these wetlands include overbank flow from the channel during precipitation and snowmelt events, shallow subsurface connections between the wetland and stream channel, direct precipitation, overland flow from adjacent uplands during precipitation and snowmelt events, and from ground water. At the headwaters of streams, these wetlands may merge with slope or depressional wetlands as the stream channel disappears (Smith and others, 1995). Water flow is bidirectional - the stream provides the wetland with water when streamflows are high, and the wetlands slowly drain back to the stream during lower flows. A high water table in the soils and sediments near the stream may also provide a secondary source of water to these wetlands. In a large wetland with a stream running through it, only the part affected by the stream would be classified as Riverine. On Mt. Desert Island, all streams are small, and flooding usually cannot reach a great distance into an adjacent wetland. For this classification, wetland areas adjacent to a stream, but further than $50 \mathrm{~m}$ from it, are not considered to be affected by the stream and are not classified as riverine. This is an arbitrary distance, as data on how far a stream's effect extends into adjacent wetlands are not available.

One variable that does affect the formation of riverine wetlands is the presence of beavers and their dams. Beaverrelated flow restriction often causes wetland formation in areas where a wetland may not otherwise form or may otherwise be much smaller. Human activities also may cause flow restrictions in streams, resulting in changes in the size or presence of wetlands. Although beaver dams and other flow restrictions do not necessarily affect the sources of water to wetlands, they can be important in the character of the hydrology of a wetland. This HGM classification does not specifically incorporate sources of flow restriction, because they are not apparent at the 1:24,000 scale of maps used in the classification. This HGM classification does allow for the presence of beaver dams and other flow restrictions to be noted for wetlands where they are known to exist. This additional information would assist in the interpretation of future site-specific hydrodynamic data.

\section{Riverine-Upper Perennial}

These wetlands are associated with perennial streams in areas of high ground-water levels. Upper Perennial Riverine wetlands lose surface water to the adjacent channel after flooding, to evapotranspiration, or as seepage to ground water if the stream is a losing stream at the wetland location. These wetlands may be wooded or have shrub-scrub or emergent vegetation. Wetlands that are adjacent to streams but only provide flow to the streams (flow is unidirectional) are not considered riverine wetlands. An example of an upper perennial riverine wetland is shown in figure 3 .

\section{Riverine-Nonperennial}

Nonperennial riverine wetlands on Mt. Desert Island are differentiated from upper perennial riverine wetlands in that the dominant source of water is from intermittent or ephemeral streams (as mapped on a 7.5-minute USGS topographic map). Additional water sources to the wetland can be from overland flow, precipitation, tributary inflow, interflow from surrounding uplands, and ground water. An example of a nonperennial riverine wetland is shown in figure 4 .

\section{Riverine-Tidal}

Tidal riverine wetlands are found along the coast and in estuaries. These wetlands are under the hydrologic influence of the tides in the Atlantic Ocean and its estuaries, but are not saline. They interface with tidal fringe wetlands (including salt marshes), but are distinguished when tidal flow (bidirectional-flow) is diminished relative to river or streamflow as the dominant water source. Salinities of 5 ppt or less are required in these wetlands (Smith and others, 1995). Additional water sources may be ground-water discharge and precipitation. Tidal riverine wetlands do not tend to dry out for long periods because water-table elevations are controlled primarily by sea surface elevation. These wetlands lose water by tidal exchange, overland flow to tidal creek channels, and by evapotranspiration. Organic matter often accumulates in higher elevation marsh areas (Smith and others, 1995). 
Table 1. Hydrogeomorphic classification for Mt. Desert Island, Maine.

\begin{tabular}{|c|c|c|c|}
\hline \multicolumn{2}{|c|}{ Hydrogeomorphic subclass } & \multirow{2}{*}{ Landscape setting } & \multirow{2}{*}{ Source of water } \\
\hline Number & Name & & \\
\hline 1 & Riverine-Upper Perennial & $\begin{array}{l}\text { Within } 50 \text { meter of a perennial stream, } \\
\text { roughly same altitude as the stream }\end{array}$ & $\begin{array}{l}\text { Primarily lateral exchange with perennial } \\
\text { 1st/2nd order stream, may also have } \\
\text { ground-water inflow }\end{array}$ \\
\hline 2 & Riverine-Nonperennial & $\begin{array}{l}\text { Within } 50 \text { meter of an intermittent stream, } \\
\text { roughly same altitude as the stream }\end{array}$ & $\begin{array}{l}\text { Primarily lateral exchange with inter- } \\
\text { mittent/nonperennial stream, may also } \\
\text { have ground-water inflow }\end{array}$ \\
\hline 3 & Riverine-Tidal & $\begin{array}{l}\text { Within } 50 \text { meter of a tidal stream, roughly } \\
\text { same altitude as the stream }\end{array}$ & $\begin{array}{l}\text { Primarily lateral exchange with tidal } \\
\text { freshwater stream; flooding from tidal } \\
\text { freshwater stream; may also have } \\
\text { ground-water inflow }\end{array}$ \\
\hline 4 & Depressional-Closed & $\begin{array}{l}\text { In a topographic depression (hills on } \\
\text { two or more sides), no surface inflow or } \\
\text { outflow }\end{array}$ & $\begin{array}{l}\text { Inflow from ground water/precipitation/ } \\
\text { overland flow }\end{array}$ \\
\hline 5 & Depressional-Semiclosed & $\begin{array}{l}\text { In a topographic depression (hills on } \\
\text { two or more sides), some surface-water } \\
\text { outflow }\end{array}$ & $\begin{array}{l}\text { Inflow from ground water/precipitation/ } \\
\text { overland flow }\end{array}$ \\
\hline 6 & Depressional-Open & $\begin{array}{l}\text { In a topographic depression (hills on two } \\
\text { or more sides), surface-water inflow and } \\
\text { outflow }\end{array}$ & $\begin{array}{l}\text { Inflow from ground water/precipitation/ } \\
\text { overland flow/stream inflow from } \\
\text { upstream }\end{array}$ \\
\hline 7 & $\begin{array}{l}\text { Depressional-No Ground } \\
\text { Water Input }\end{array}$ & $\begin{array}{l}\text { In a topographic depression (hills on } \\
\text { two or more sides), but underlain by } \\
\text { Presumpscot Formation, may have } \\
\text { surface-water inflows or outflows }\end{array}$ & $\begin{array}{l}\text { Precipitation/overland flow/stream } \\
\text { inflow from upstream }\end{array}$ \\
\hline 8 & Mineral Soil Flat & $\begin{array}{l}\text { Wide, flat area, low topographic relief in } \\
\text { surrounding area, mineral soils }\end{array}$ & Precipitation \\
\hline 9 & Organic Soil Flat & $\begin{array}{l}\text { Wide, flat area, low topographic relief in } \\
\text { surrounding area, organic soils }\end{array}$ & Precipitation \\
\hline 10 & Tidal Fringe & $\begin{array}{l}\text { Adjacent to tidal saltwater body/estuary, } \\
\text { within } 50 \text { meter of limit of saltwater } \\
\text { influence }\end{array}$ & $\begin{array}{l}\text { Overbank flow (lateral exchange) from } \\
\text { estuary or other saltwater body }\end{array}$ \\
\hline 11 & Lacustrine Fringe & $\begin{array}{l}\text { Adjacent to large open-water lake/pond } \\
\text { (within } 100 \text { meter, same altitude, lake/ } \\
\text { pond must be large enough to control } \\
\text { water level in wetland) }\end{array}$ & $\begin{array}{l}\text { Overbank flow (lateral exchange) from } \\
\text { lake, may also have ground-water inflow }\end{array}$ \\
\hline 12 & Slope & On a sloping surface or hillside & $\begin{array}{l}\text { Return flow (discharge) from ground } \\
\text { water }\end{array}$ \\
\hline
\end{tabular}




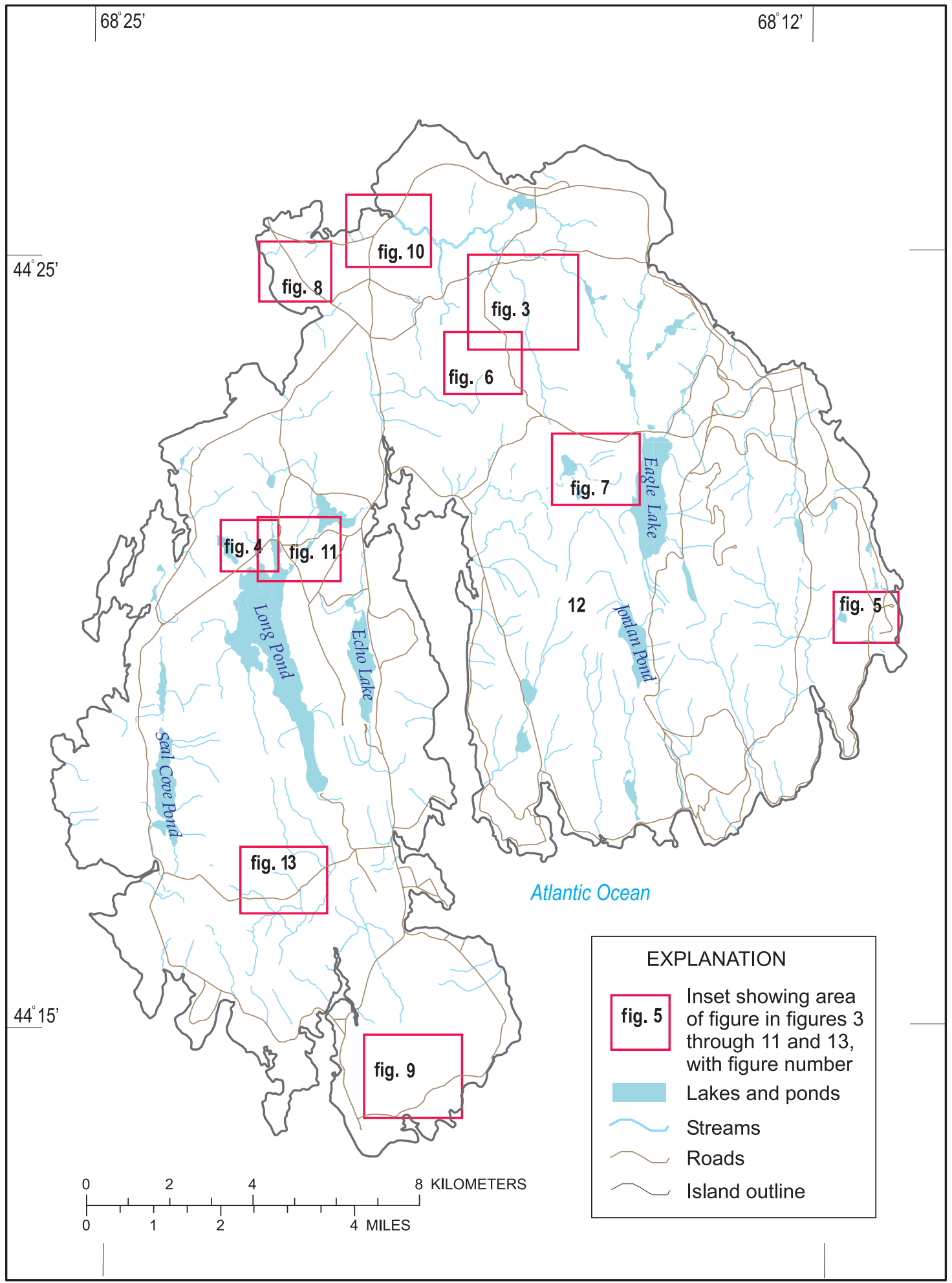

Base from U. S. Geological Survey Digital line graph Bass Harbor, Bar Harbor,

Figure 2. Index map showing location of example wetland figures, Mt. Desert Island, Maine. 


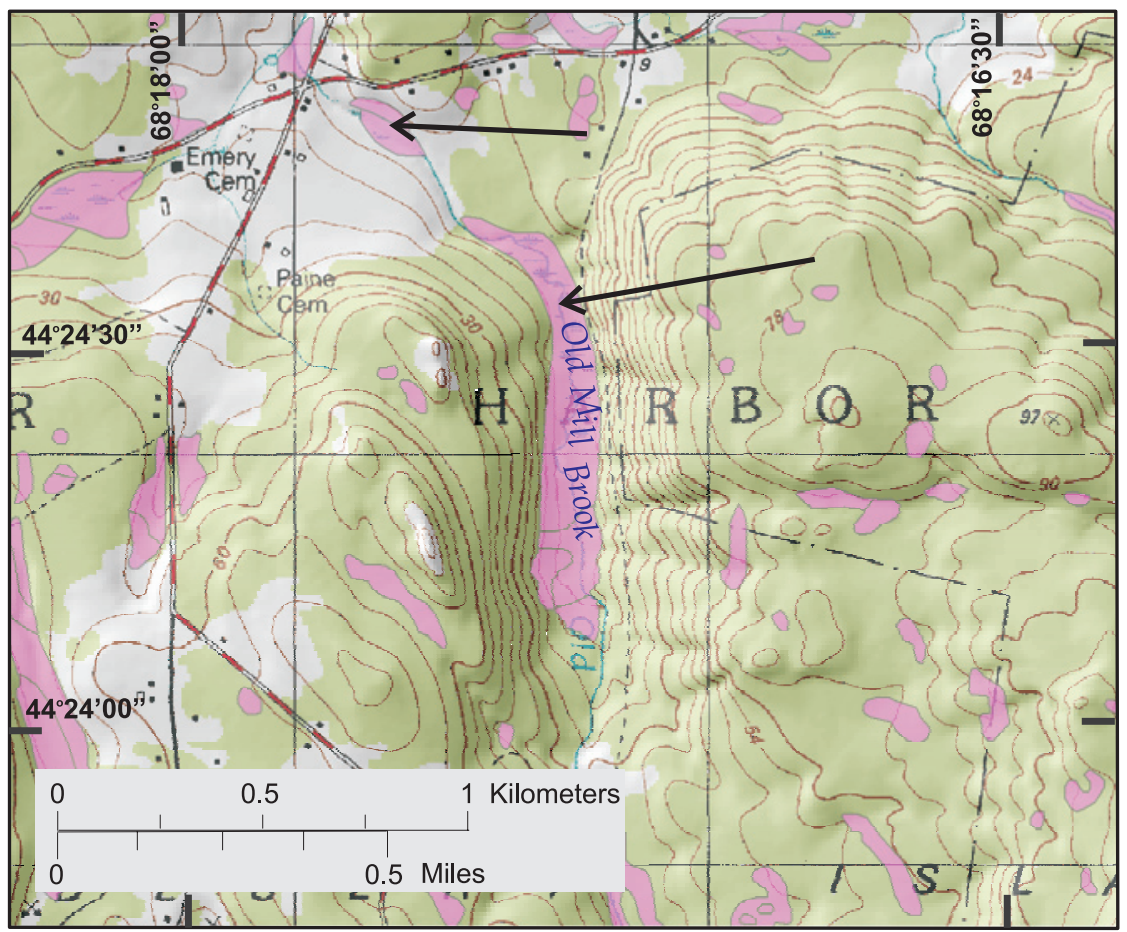

\section{EXPLANATION}

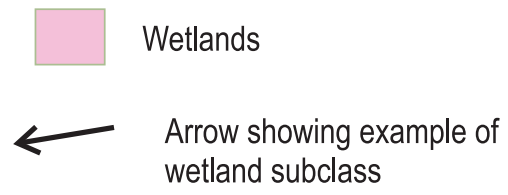

Map Base from 1:24,000

Digital Raster Graph

U.S. Geological Survey,

Bar Harbor quadrangle.

Shaded relief from 10-m

Digital Elevation Model.

Wetland locations from

U.S. Fish and Wildlife

Service National Wetland

Inventory.

Figure 3. Riverine-Upper Perennial example: wetlands adjacent to Old Mill Brook, Bar Harbor, Maine. (Index map shown in figure 2.)

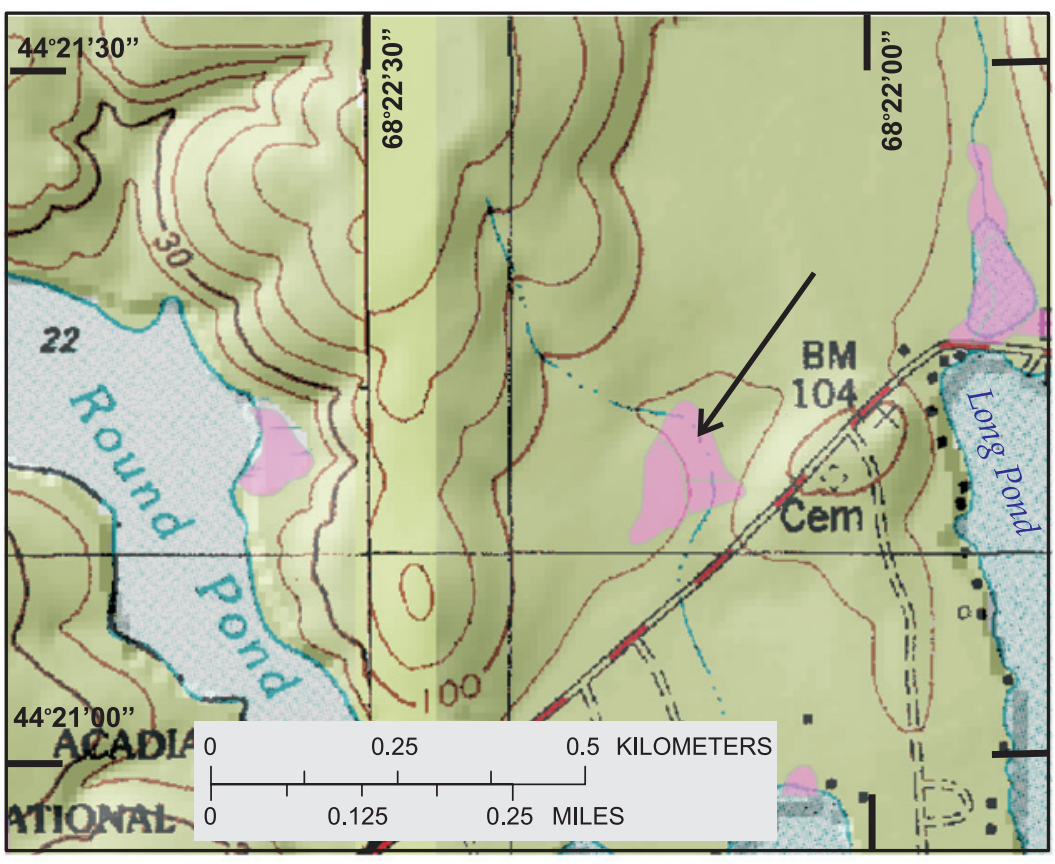

Figure 4. Riverine-Nonperennial example: wetland east of Round Pond and north of Long Pond, Mount Desert, Maine. (Index map shown in figure 2.) 

and Examples

Because salinities and the extent of tidal influence on coastal streams is not shown on 1:24,000-scale maps, these wetlands can only be differentiated from other coastal riverine wetlands after collecting information in the field.

\section{Depressional Wetlands}

Depressional wetlands on Mt. Desert Island are a major class of wetlands that form in topographic depressions or basins (which may be closed, semiclosed, or open) where inflowing surface water accumulates. Water sources for these wetlands include direct precipitation, ground-water discharge, overland flow, and shallow subsurface seepage from adjacent uplands ("interflow"). The local hydrologic gradient is primarily from the uplands surrounding the wetland toward the center of the depression. Gaps in the surrounding uplands may allow for stream inlets and (or) outlets. Water flows out of depressional wetlands through evapotranspiration, groundwater recharge, or, if stream channels exist, through perennial or intermittent surface-water flow (Smith and others 1995). Peat deposits may develop in some depressional wetlands. Depressional wetlands may have open water in the center, but the depth of water generally does not exceed $2 \mathrm{~m}$ and is usually much less (open water bodies with depths greater than $2 \mathrm{~m}$ are defined as lacustrine wetlands or water bodies in the NWI, rather than palustrine wetlands).

\section{Depressional-Closed}

Closed depressional wetlands lack any discernible surface-water inlets or outlets (Smith and others, 1995). Flow is from ground-water discharge, overland flow, and shallow seepage from adjacent uplands ("interflow"); outflow is through ground-water seepage and evapotranspiration. Vernal pools and kettle-hole wetlands are examples of closed depressional wetlands. An example of a closed depressional wetland on Mt. Desert Island is shown in figure 5.

\section{Depressional-Semiclosed}

Semiclosed depressional wetlands are similar to closed depressional wetlands, although they have one or more surface-water outlets (Smith and others, 1995), and are much more common than closed depressional wetlands. They have no discernible surface-water inlet, and sources of water are from precipitation, overland flow, ground-water discharge, and shallow seepage from adjacent uplands ("interflow"). Water drains these wetlands through intermittent or perennial streams, ground-water recharge, and (or) evapotranspiration. Peat deposits may develop in some semiclosed depressional wetlands. An example of a semiclosed depressional wetland is shown in figure 6 . (The opposite type of semiclosed depressional wetland, with surface water inlets but no outlet, is theoretically possible but not found in the humid northeastern
U.S. It is found where evapotranspiration is a dominant sink, such as in the western U.S.)

\section{Depressional-0pen}

Open depressional wetlands are distinguished from other depressional wetlands by discernible surface-water inlets and outlets (Smith and others, 1995). These wetlands may be further differentiated into open, ground-water depressional wetlands-where the primary source of water is ground water-and open, surface-water depressional wetlandswhere the primary source of water is surface-water runoff, precipitation, overland flow, or interflow. These wetlands are supported by a locally high water table and are common on Mt. Desert Island (Calhoun and others, 1994). These wetlands exist in till, glaciomarine, and bedrock settings. Open depressional wetlands may have a corridor of riverine wetland along a stream within the wetland. An example of an open depressional wetland is shown in figure 7 .

\section{Depressional-No Ground-Water Input}

In depressional settings where the glaciomarine Presumpscot Formation forms a thick blanket of lowpermeability sediments below the wetland, a wetland may be cut off from ground-water inflow. If a depressional wetland is in an area where the hydraulic head in the underlying aquifer is higher than in the wetland, and ground water would normally discharge to the wetland were it not for the lowpermeability sediments, that wetland would be classified as depressional with no ground-water input. The presence of the Presumpscot Formation itself, however, does not automatically mean that water cannot flow from the ground water to the wetland. The Presumpscot Formation is fractured in many places, and the thickness may vary from less than a meter to more than $20 \mathrm{~m}$ (unpublished well logs from the Maine Geological Survey). Most wetlands that are developed on glaciomarine deposits in depressional settings on Mt. Desert Island probably receive some ground-water inflow because of the variation in thickness and fracturing of the deposits, and would be considered semiclosed depressional or open no ground-water input depressional wetlands. The no groundwater input depressional wetlands subclass should be used only when sufficient field data have been collected to rule out ground-water discharge to the wetland, and cannot be assigned using map data alone.

\section{Mineral Soil Flats}

Mineral soil flats are wetlands developed on relatively flat ground, which includes interfluves (flat areas between streams draining in the same general direction), other relatively flat upland areas, and large flood-plain terraces (Smith and others, 1995). The dominant source of water 


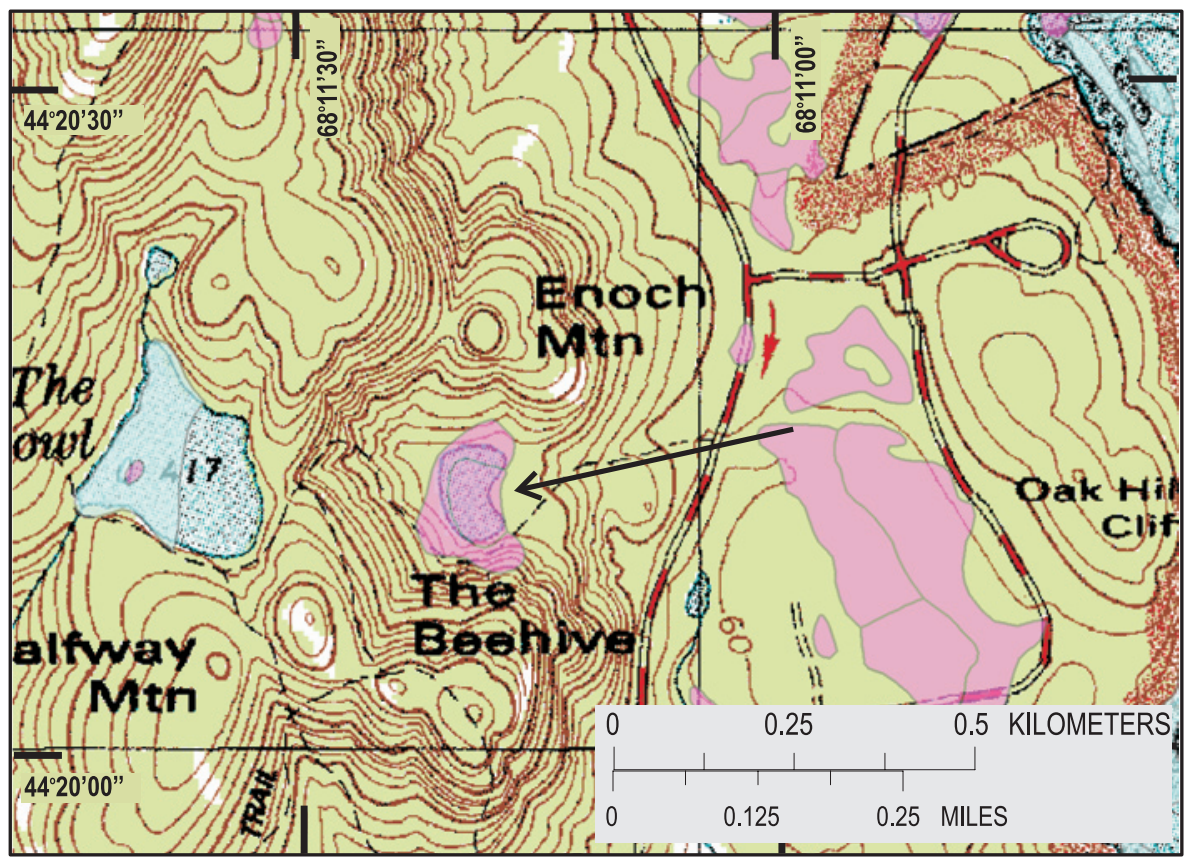

Figure 5. Depressional-Closed example: wetland north of The Beehive, Bar Harbor, Maine. (Index map shown in figure 2.)

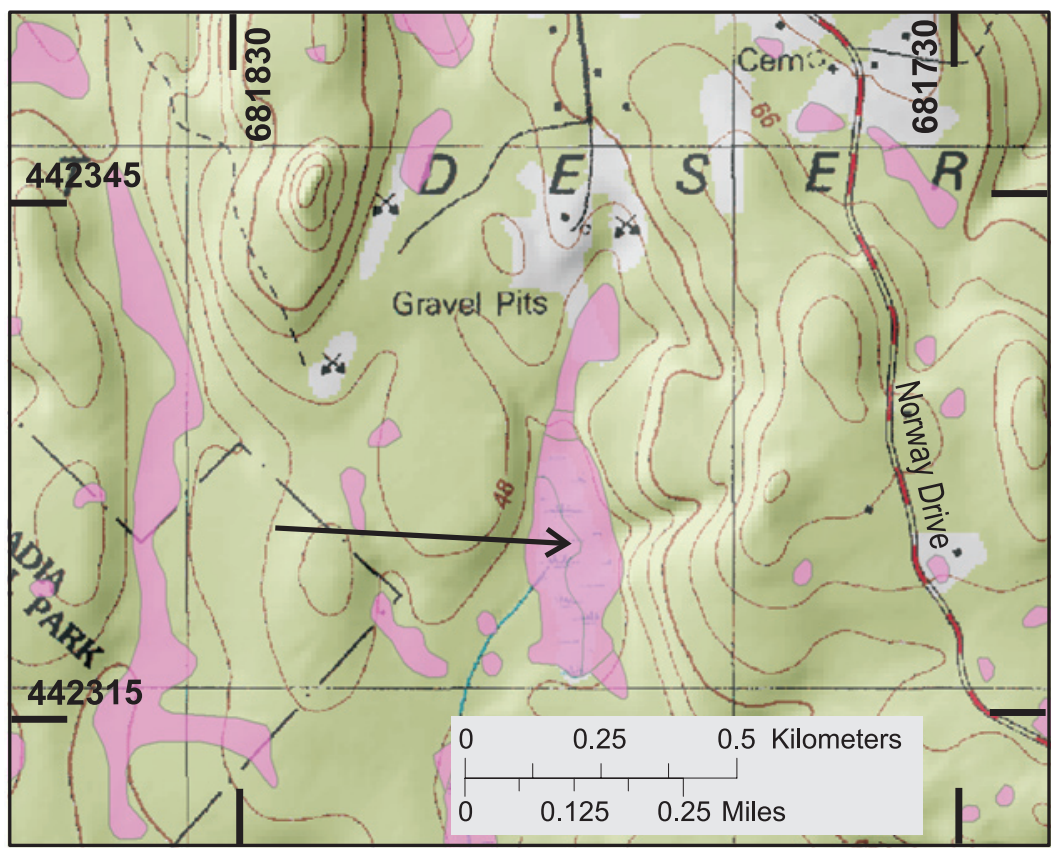

Figure 6. Depressional-Semiclosed example: wetland west of Norway Drive, Bar Harbor, Maine. (Index map shown in figure 2.) 


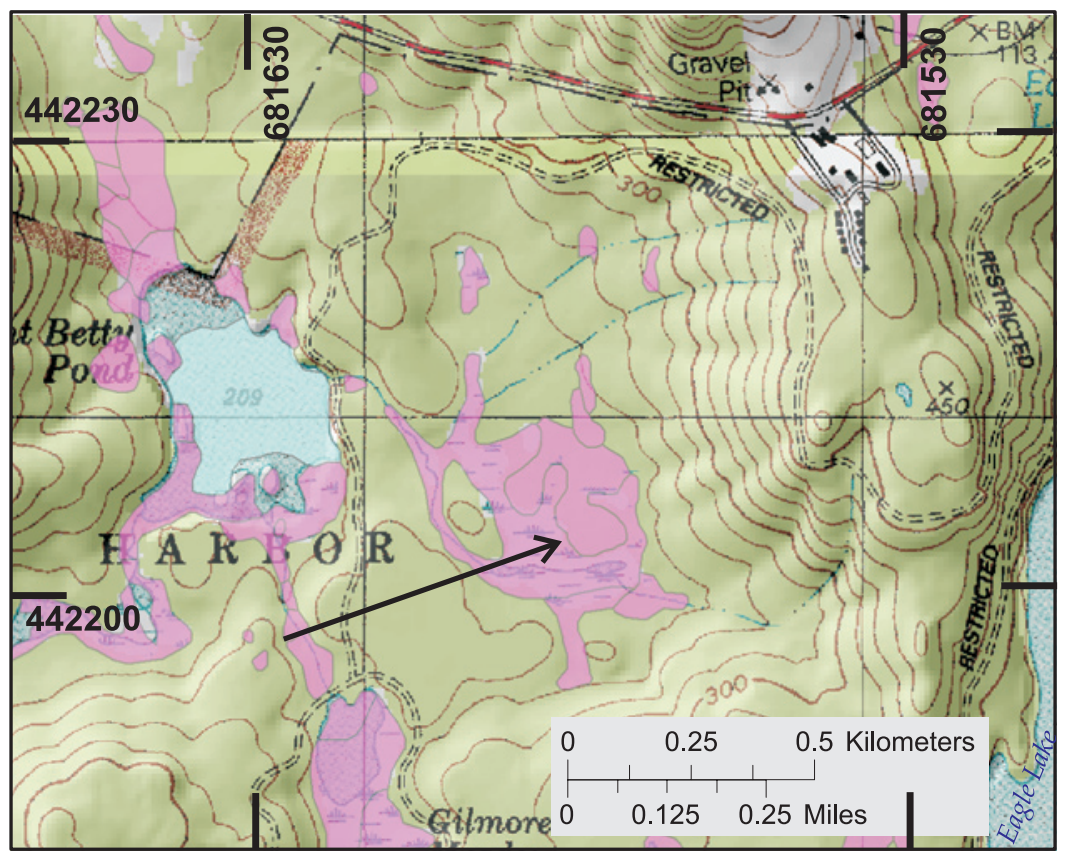

Figure 7. Depressional Open example: wetland west of Eagle Lake, Bar Harbor, Maine. (Index map shown in figure 2.)

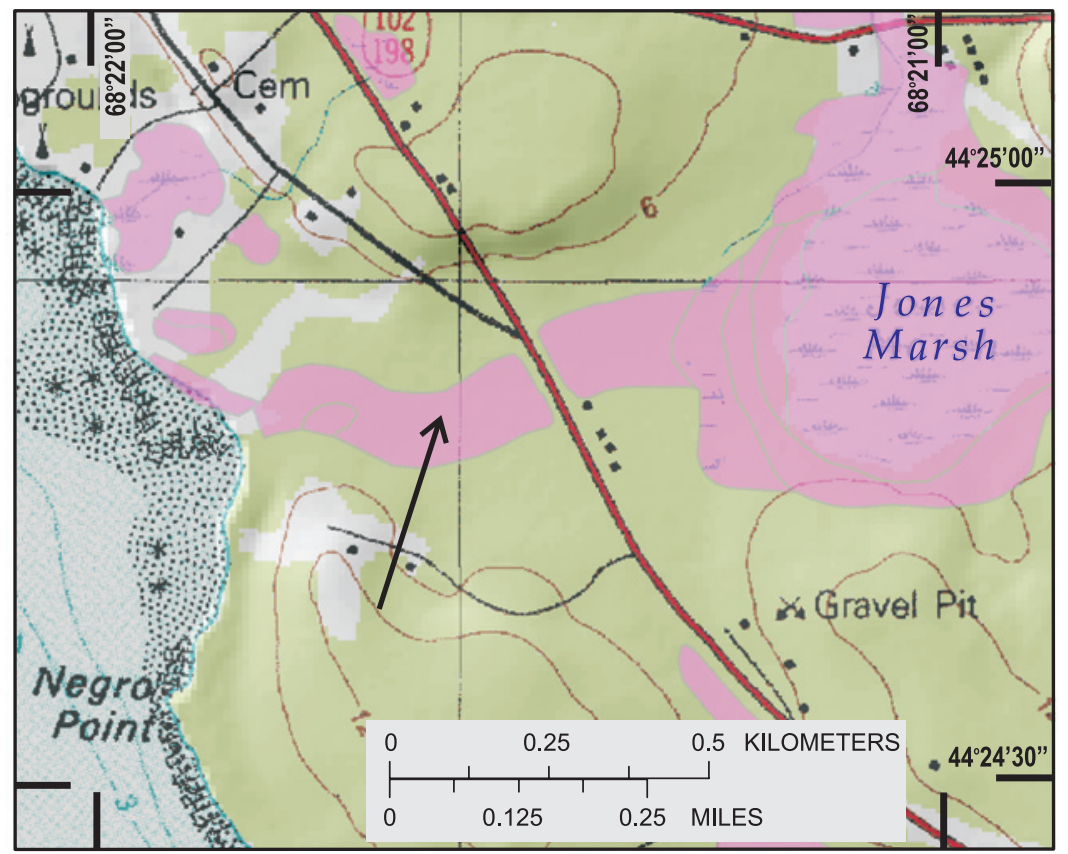

Figure 8. Mineral Soil Flat example: wetland west of Route 102/198 near Jones Marsh, Bar Harbor, Maine. (Index map shown in figure 2.) 
is precipitation. Mineral soil flats are distinguished from depressional and slope wetlands in that they receive virtually no ground-water inputs, although the water level is maintained by a locally-high water table, which prevents drainage of runoff and precipitation. Water drains these wetlands through overland flow, evapotranspiration, and seepage to ground water. Vertical drainage tends to be poor, because of clayey soils, hardpans, slow rates of lateral drainage, and low hydraulic gradients (Smith and others, 1995). On Mt. Desert Island, the clay-rich Presumpscot Formation commonly is present at depth beneath these wetlands. Mineral soil flats can eventually become organic soil flats if peat accumulates. Common examples of mineral soil flat wetlands are various types of forested wetlands with hydric (seasonally watersaturated) soils. Riverine wetlands may be found near streams within larger areas of soil flat wetlands. An example of a mineral soil flat wetland is shown in figure 8 .

\section{Organic Soil Flats}

Organic soil flat wetlands, also referred to as extensive peatlands, are differentiated from mineral soil flats primarily by the vertical accretion of organic matter (Smith and others, 1995). They are common on flat interfluves; they also may have been former large depressional wetlands that have become filled with peat to form relatively large, flat surface areas (Smith and others, 1995). The dominant source of water is precipitation. Water loss is by evapotranspiration, stream flow, overland flow, and seepage to ground water. Organic soil flats share many characteristics with raised bogs but do not have the convex upward form of bogs and the low-nutrient conditions for plants that bogs provide. An example of an organic soil flat wetland is shown in figure 9 .

\section{Tidal Fringe}

Tidal fringe wetlands are found in estuaries and along the coast; water levels are under the influence of local tidal fluctuations (Smith and others, 1995). These wetlands may merge landward with other types of wetlands, including riverine wetlands, mineral soil flats, or organic soil flats. Pore-water salinities of 5 to $30 \mathrm{ppt}$ distinguish tidal fringe wetlands from riverine-tidal wetlands (Smith and others, 1995). Because salt marshes are within this salinity range, they are considered tidal fringe wetlands. Water sources also include direct precipitation and may include ground-water discharge. Tidal fringe wetlands lose water through tidal exchange, evapotranspiration, and overland or subsurface flow to tidal creek channels (Smith and others, 1995). Tidal fringe wetlands seldom dry out because they are frequently flooded by high tides, especially bimonthly spring tides, and watertable elevations are controlled primarily by sea-level elevation. Organic matter tends to accumulate at higher elevation marsh areas where flooding is less frequent and shoreline wave erosion is not a factor. An example of a tidal fringe wetland is shown in figure 10 .

\section{Lacustrine Fringe}

Lacustrine fringe wetlands are located adjacent to lakes and ponds where the water level of the lake maintains the water level in the wetland (Smith and others, 1995). Water also enters these wetlands through direct precipitation and groundwater discharge. Ground-water discharge may dominate where lacustrine fringe wetlands contact adjacent uplands or slope wetlands. Lacustrine fringe wetlands lose water through overland or subsurface flow to the lake or pond (following flooding), and by evapotranspiration. Organic matter may accumulate in areas protected from shoreline wave erosion. Water can be up to $2 \mathrm{~m}$ deep in some areas. Wetlands that are adjacent to small ponds (often considered a part of the wetland itself), and that do not have another independent source of water (such as stream inflows), are not included in the lacustrine fringe subclass, but are generally classified as depressional wetlands of some sort. For this HGM classification system, portions of wetlands adjacent to a lake or pond, but further than $100 \mathrm{~m}$ from it, are not considered to be affected by the water body and, therefore, are not classified as lacustrine fringe. The $100 \mathrm{~m}$ is an arbitrary distance, because data are not readily available that could help determine how far the a water body's influence may extend into an adjacent wetland. This distance may vary with lake level, elevation of the wetland, vegetation, and other factors. An example of a lacustrine fringe wetland would be the wetland surrounding Ripple Pond in the town of Mount Desert (fig. 11).

\section{Slope}

Slope wetlands normally exist on sloped land where ground water discharges to the land surface (Smith and others, 1995). Many geologic settings can produce this effect; on Mt. Desert Island this may occur because a lower-permeability layer (fractured bedrock, for example) forces ground water to the surface saturating the surficial soils (fig. 12). Elevation gradients range from slight slopes to steep hillsides. Slope wetlands are distinguished from depressional wetlands because there is no basin shape, and the wetlands are on sloping surfaces. The dominant water source is ground water, but precipitation and interflow from surrounding uplands also may contribute water. Slope wetlands lose water by evapotranspiration, by saturated flow back into ground water on their downslope side, and overland surface flow. Some slope wetlands appear on a topographic map to be similar to riverine wetlands, but these slope wetlands are always slightly higher in elevation than the stream and supply the stream with water rather than the other way around. Examples of slope wetlands are shown in figure 13. 


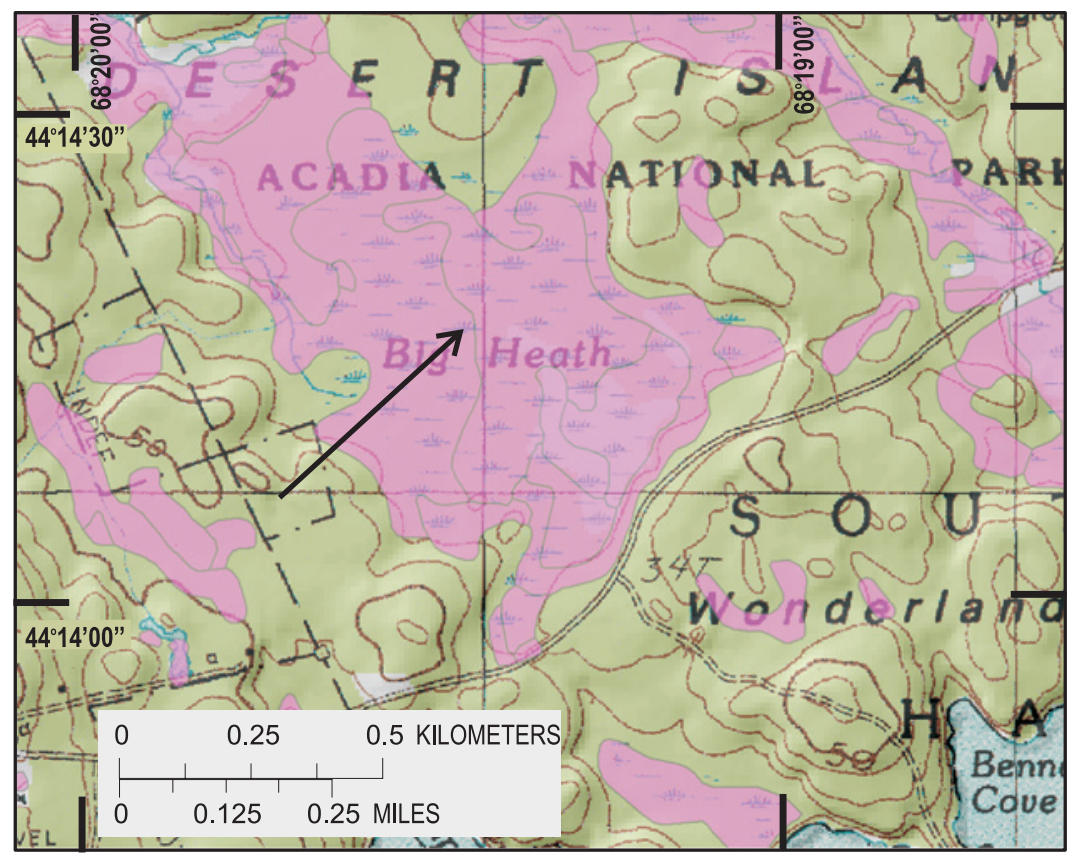

Figure 9. Organic Soil Flat example: Big Heath wetland, southeast of Bass Harbor, Southwest Harbor, Maine. (Index map shown in figure 2.)

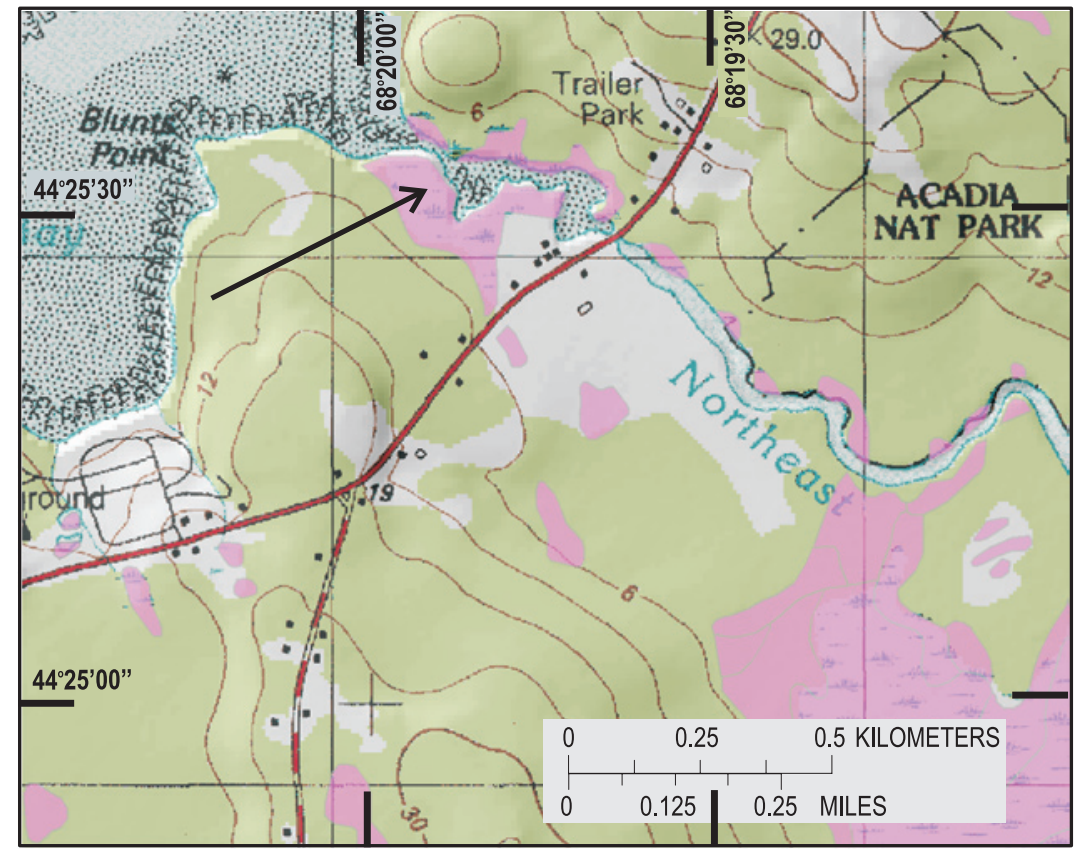

Figure 10. Tidal Fringe example: wetland at the mouth of Northeast Creek, Bar Harbor, Maine. (Index map shown in figure 2.) 


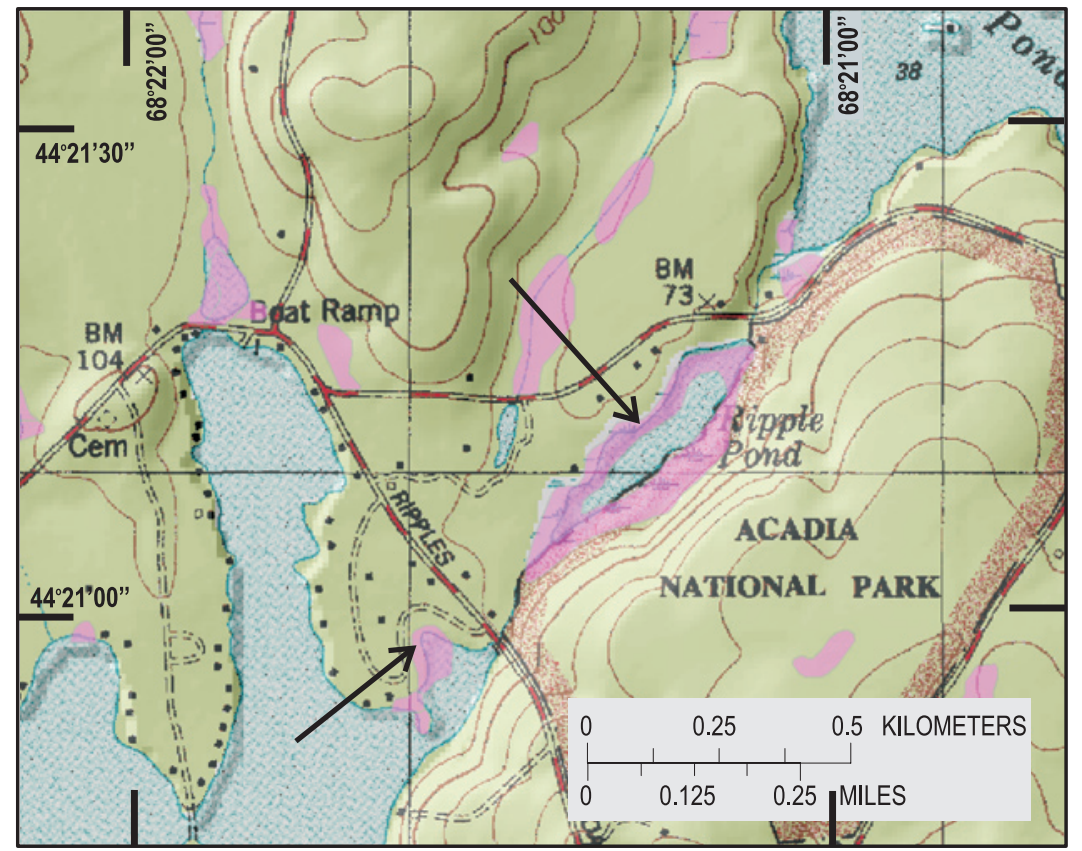

Figure 11. Lacustrine Fringe example: wetlands near Ripple Pond, west of Somes Sound, Mount Desert, Maine. (Index map shown in figure 2.)

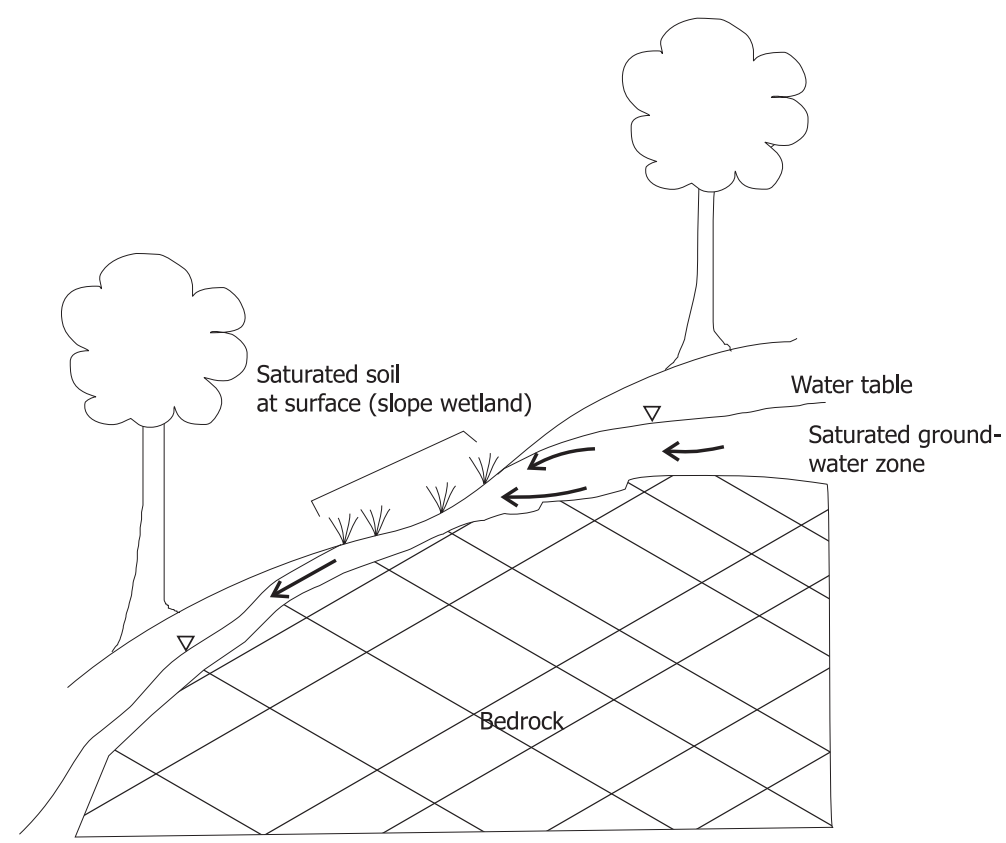

Figure 12. Schematic cross section of one example of slope wetland formation. Bedrock underlying saturated soils pinches the water table near the land surface, creating an area where the surface soils are saturated and discharging ground water, forming a slope wetland. 


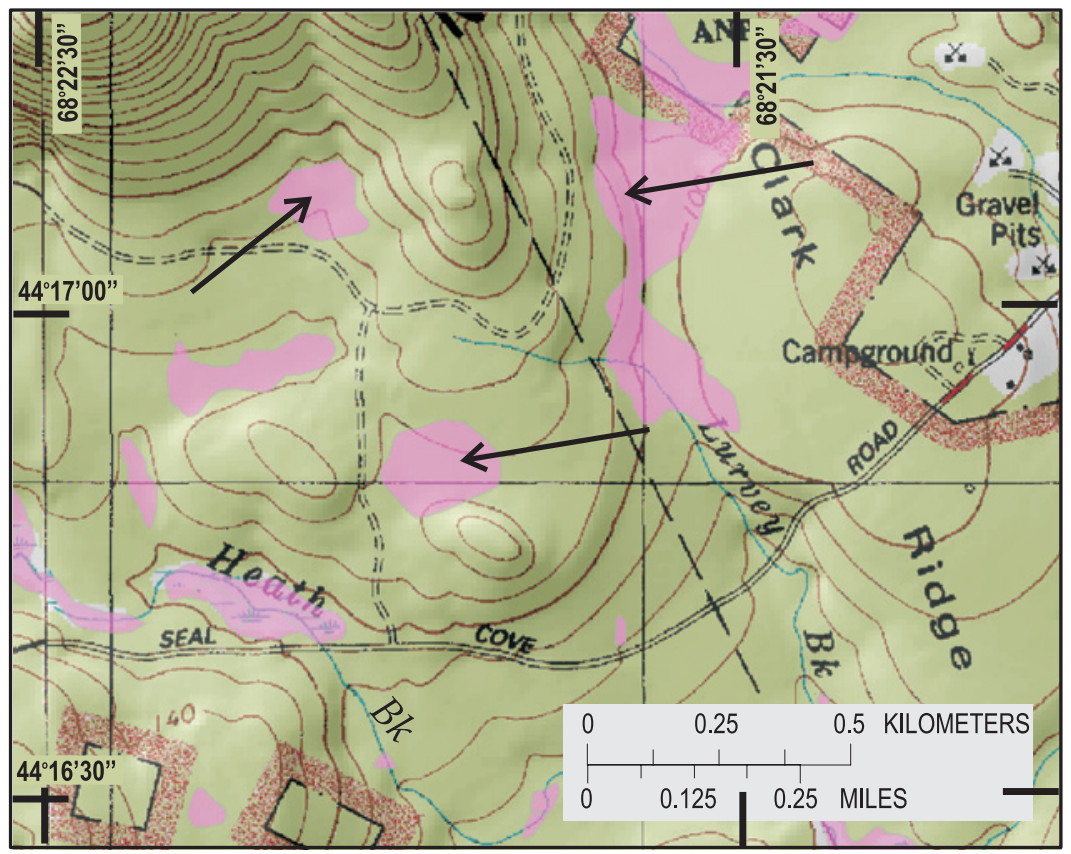

Figure 13. Slope example: wetlands in Marshall, Heath, and Lurvey Brooks watersheds, Mount Desert and Tremont, Maine. (Index map shown in figure 2.)

\section{Application of Classification System}

This HGM classification system was designed to be used in a flexible manner. An initial classification of wetlands on Mt. Desert Island can be accomplished using available map data at a scale of 1:24,000. This initial classification may be refined for any particular wetland by collecting field data on water movement (surface-water inflows and outflows, and/or ground-water inflows or outflows) and collecting field hydroperiod data for surface water and shallow ground water in the wetland.

\section{Dichotomous Key for the Identification of Wetland Subclasses}

To assist in the classification of an individual wetland using the HGM classification, a dichotomous key was developed for Mt. Desert Island (table 2). The key consists of a series of paired choices called couplets. Each couplet presents the user with two alternative choices that distinguish one group of wetlands from another. The user chooses one alternative, and the answer determines which couplet is referred to next, until a wetland type is determined. The key was developed to be used with GIS data as much as possible.

\section{Expected Hydroperiod Characteristics}

Previous research on wetland hydrology and HGM classification has shown that different HGM classes exhibit distinct hydroperiod characteristics (Schaffer and others, 1999). (In this report, the term "hydroperiod" refers to water level changes over time, both in duration of flooding and degree of rise and fall in response to precipitation events.) These hydroperiod characteristics reflect the source of water and how that water source can be expected to behave during a growing season. Typically, all wetland types in northern New England will be wetter (higher water levels) in the spring and early summer, with declining water levels as evapotranspiration begins to use more water than precipitation and other sources of water can provide. Generally, the regional and local water tables will also decline during the summer. As regional and local water tables decline, streamflow will decline, lake levels will decline, and ground-water discharge to depressional, riverine, and slope wetlands will decline. The patterns of water-level decline, ground-water gradients with respect to standing water, the rate at which water levels change (both long-term and in response to precipitation), and the duration of standing water all reflect the source of water and surficial geology. The expected hydroperiod characteristics of each wetland subclass are listed in table 3. 
Table 2. Hydrogeomorphic Classification Key for Mt. Desert Island, Maine.

1. Is the wetland adjacent to saltwater or an estuary?

Yes. Tidal Fringe

No 2

2. Is the wetland immediately adjacent to an open-water lake/pond?

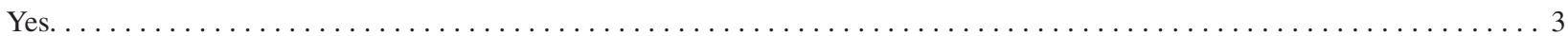

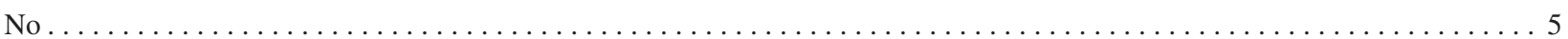

3. Is the wetland area in question within $100 \mathrm{~m}$ of the lake/pond and at the same elevation?

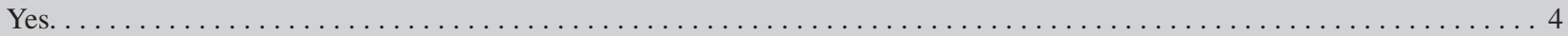

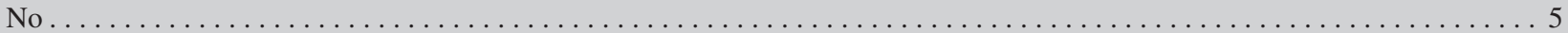

4. Is the pond large enough to supply water to the wetland, or does the pond have an independent source of water such as a stream flowing into it?

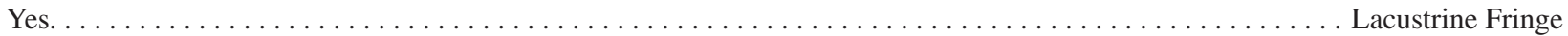

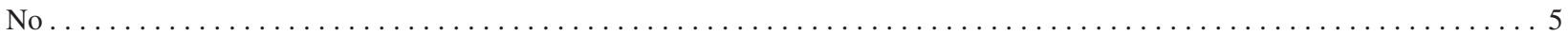

5. Is there a river or stream running through the wetland?

Yes.

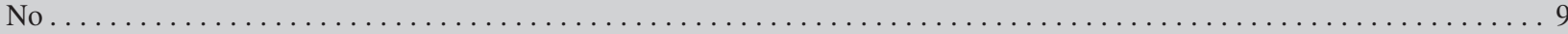

6. Does the stream appear to be the dominant source of water for the wetland (that is, is the stream at the same altitude as most of the wetland, and is the wetland area in question within $50 \mathrm{~m}$ of the stream)?

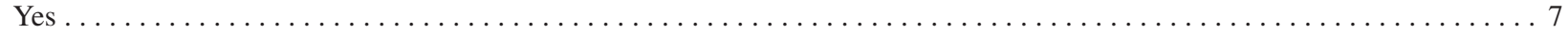

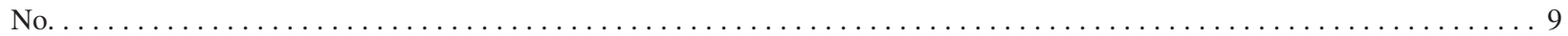

7. Is the stream tidal or nontidal?

Tidal Riverine-Tidal

Nontidal .8

8. Is the stream perennial or nonperennial?

Perennial Riverine-Upper Perennial

Nonperennial. Riverine-Nonperennial

9. Is the wetland on a sloping surface (does it cross contour lines or otherwise appear to be on a slope)?

Yes Slope

No 10

10. Does the wetland appear to be in a topographic basin or depression (nearby hills on two or more sides)?

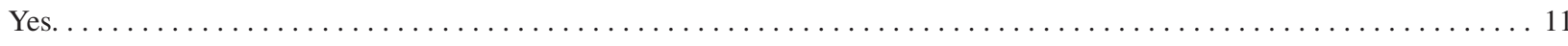

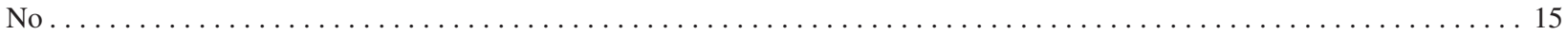

11. Is the wetland set in a large, low-slope area, where the only obvious source of water is precipitation?

Yes. .

No

12. Is the wetland underlain by Presumpscot Formation clays, and has field data shown that there is no ground-water input to the wetland?

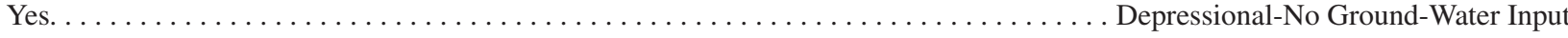

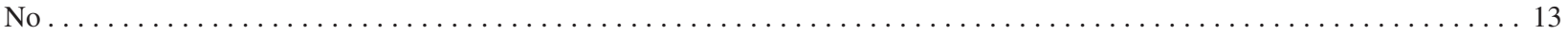

13. Does the wetland have surface-water outflows?

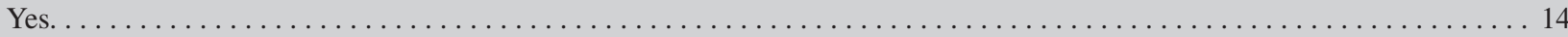

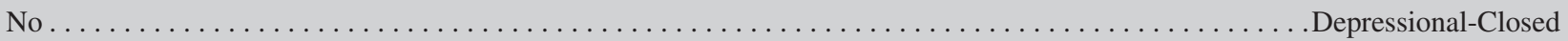

14. Does the wetland have surface-water inflows?

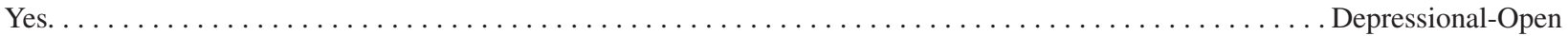

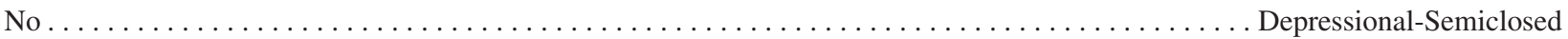

15. Is the wetland underlain by soils that are

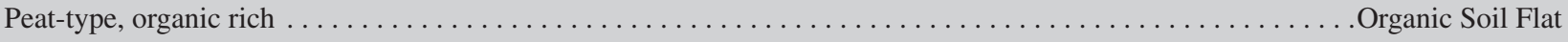

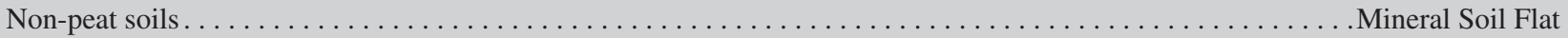


Table 3. Expected hydroperiod characteristics for hydrogeomorphic subclasses, Mt. Desert Island, Maine.

\begin{tabular}{|c|c|c|c|c|}
\hline $\begin{array}{c}\text { Hydrogeomorphic } \\
\text { subclass }\end{array}$ & Hydraulic gradients & Duration of standing water & $\begin{array}{c}\text { Water-level changes } \\
\text { over summer }\end{array}$ & Rate of water-level change \\
\hline Lacustrine Fringe & $\begin{array}{l}\text { Relatively flat gradients, } \\
\text { horizontal from lake; } \\
\text { upwards from deep } \\
\text { ground water }\end{array}$ & $\begin{array}{l}\text { Should have standing } \\
\text { water all summer, as long } \\
\text { as lake level remains } \\
\text { relatively constant }\end{array}$ & $\begin{array}{l}\text { Relatively constant, } \\
\text { small declines over } \\
\text { summer if lake level drops }\end{array}$ & $\begin{array}{l}\text { Slow changes with } \\
\text { precipitation events }\end{array}$ \\
\hline $\begin{array}{l}\text { Riverine- } \\
\text { Upper Perennial }\end{array}$ & $\begin{array}{l}\text { Often horizontal towards } \\
\text { stream, but changing } \\
\text { direction when streamflow } \\
\text { is high; upwards from } \\
\text { deep ground water } \\
\text { in places; may see }\end{array}$ & $\begin{array}{l}\text { Standing water in early } \\
\text { summer, declining as } \\
\text { streamflows decline. } \\
\text { Little or no standing } \\
\text { water during stream } \\
\text { base flow periods }\end{array}$ & $\begin{array}{l}\text { Slow declines to base } \\
\text { of stream bed unless } \\
\text { stream drys, then rapid } \\
\text { declines with local } \\
\text { ground-water table }\end{array}$ & $\begin{array}{l}\text { Relatively rapid rises with } \\
\text { precipitation if precipitation } \\
\text { is enough to flood stream. } \\
\text { Slower changes (if any) late } \\
\text { in growing season when soil } \\
\text { moisture is depleted }\end{array}$ \\
\hline
\end{tabular}

downwards gradient when stream segment is losing

$\begin{array}{ll}\text { Riverine- } & \text { Often horizontal towards } \\ \text { Nonperennial } & \text { stream, but changing } \\ & \text { direction when streamflow } \\ \text { is high; upwards from } & \text { deep ground water in } \\ & \text { places; may see downward } \\ & \text { gradient when stream } \\ & \text { segment is losing }\end{array}$

\section{Riverine-}

Tidal

\section{Often horizontal towards} stream, but changing direction when streamflow is high, with small daily variability from tidal stage changes; upward from deep ground water in places
Standing water in early summer, declining as streamflows decline. Little or no standing water during stream base flow periods
Steady declines to base of stream bed until stream drys, then rapid declines with local ground-water table
Relatively rapid changes with precipitation if precipitation is enough to flood stream. Slower changes (if any) late in growing season when soil moisture is depleted

\section{Standing water in early} summer, declining as streamflows decline. Little or no standing water during stream base flow periods

\section{Relatively rapid rises with pitation in growing season when soil} mats

Relatively rapid changes with precipitation if precipitation is enough to flood stream. Slower changes (if any) late in growing season when soil moisture is depleted

Unsteady declines to base of stream bed. Pore water level would not fall below high-tide influence.
Rapid changes with precipitation events if overland flow develops. Otherwise slow changes

$\begin{array}{ll}\text { Depressional- } & \text { Upward gradients locally, } \\ \text { Closed } & \text { may have downward } \\ \text { gradients on downstream } \\ \text { side as water re-enters the } \\ \text { ground-water system }\end{array}$

\section{Depressional-} Semiclosed

\section{Upward gradients locally,} downwards on downstream side as water re-enters the ground-water system

\begin{abstract}
Standing water likely, but may dry out at end of season or in dry years
\end{abstract} Slow decline if hills are
high, may be faster decline
if hills are lower

\section{Standing water likely after precipitation events, but not expected year round \\ Slow decline if hills are high, may be faster decline if hills are lower} because of surface outflow
Rapid changes with precipitation events if overland flow develops. Otherwise slow changes

Rapid changes with precipitation events if overland flow develops. Otherwise slow changes

$\begin{array}{lll}\begin{array}{l}\text { Standing water at } \\ \text { beginning of growing }\end{array} & \begin{array}{l}\text { Continuous decline } \\ \text { over summer, except }\end{array} & \begin{array}{l}\text { Rapid changes with } \\ \text { precipitation events }\end{array} \\ \text { season, but declining rapidly } & \text { for precipitation events. } & \text { and with hot weather as } \\ \text { as evapotranspiration } & \begin{array}{l}\text { Decline may be rapid } \\ \text { during dry periods }\end{array} & \begin{array}{l}\text { evapotranspiration draws } \\ \text { down water levels }\end{array} \\ \text { increases } & & \end{array}$

Slow decline if hills are high, may be faster decline if hills are lower side as water re-enters the ground-water system

Slight vertical gradients; horizontal gradients towards outflow streams (if they exist)

\section{dry out at end of season or in dry years \\ Standing water likely at least at beginning of growing season, but may} DepressionalNo Ground-Water Input 
Table 3. Expected hydroperiod characteristics for hydrogeomorphic subclasses, Mt. Desert Island, Maine.-Continued

\begin{tabular}{|c|c|c|c|c|}
\hline $\begin{array}{c}\text { Hydrogeomorphic } \\
\text { subclass }\end{array}$ & Hydraulic gradients & Duration of standing water & $\begin{array}{c}\text { Water-level changes } \\
\text { over summer }\end{array}$ & Rate of water-level change \\
\hline Mineral Soil Flat & $\begin{array}{l}\text { Downward vertical } \\
\text { gradients if any; } \\
\text { horizontal gradients } \\
\text { towards surface outflow }\end{array}$ & $\begin{array}{l}\text { Standing water at } \\
\text { beginning of year, but } \\
\text { declining rapidly once } \\
\text { dry weather sets in }\end{array}$ & $\begin{array}{l}\text { Continuous decline } \\
\text { over summer, except } \\
\text { for precipitation events. } \\
\text { Decline may be rapid } \\
\text { during dry periods }\end{array}$ & $\begin{array}{l}\text { Slow changes with } \\
\text { precipitation events and } \\
\text { with dry weather as } \\
\text { evapotranspiration draws } \\
\text { down water levels }\end{array}$ \\
\hline Slope & $\begin{array}{l}\text { Upward to horizontal } \\
\text { gradients upslope; } \\
\text { downward to horizontal } \\
\text { gradients downslope; } \\
\text { horizontal gradients in } \\
\text { middle of the wetland }\end{array}$ & $\begin{array}{l}\text { Little to no standing } \\
\text { water expected }\end{array}$ & $\begin{array}{l}\text { Slow decline over the } \\
\text { summer as the local } \\
\text { water table declines }\end{array}$ & $\begin{array}{l}\text { Slow changes with } \\
\text { precipitation and } \\
\text { other events }\end{array}$ \\
\hline
\end{tabular}

It should be noted that the hydroperiod characteristics of all wetlands are somewhat similar, and the expected hydroperiod characteristics in certain subclasses overlap with those of other subclasses. Within classes and subclasses, the upstream watershed size and size of the wetland system also influence the hydroperiod. Alone, this information cannot be used to assign a subclass, but it can be used as an aid in the process. It can also be used to gain insight into likely wetland functions associated with hydrologic regime. For instance, the expected duration of standing water can help evaluate a wetland's suitability for habitat for various organisms.

\section{Example of Classifying Wetlands: A Test Case in Acadia National Park}

The preliminary HGM classification system developed here, which relies on the use of available GIS data, was tested on a set of 20 wetlands on Mt. Desert Island. An initial classification of these wetlands was done using 1:24,000-scale map data. Hydroperiod data were collected for these wetlands over two growing seasons. After the initial classification was done, these field data were examined with respect to the expected hydroperiod characteristics for each wetland in order to determine if the initial classification method assigned a subclass that was consistent with the field data.

This set of 20 wetlands was recently (2000-2001) studied as part of an effort to develop a freshwater wetland monitoring protocol at Acadia National Park. These 20 wetlands were studied specifically to determine a set of variables that would be most useful for monitoring wetland ecosystem health, but are not too costly or complicated to use in the field. Some of the variables tested were hydrologic, such as surface-water levels measured by staff gages, and shallow ground-water levels measured in wells laid out across the wetland. The wetlands represent a range of sizes (less than 0.1 to about $8.5 \mathrm{ha}$, median size $=0.6 \mathrm{ha}$ ) and a mixture of undisturbed, pristine wetlands and wetlands that have been subjected to some degree of human alteration and disturbance (fig. 14). Eleven of the wetlands were classified as disturbed and 9 were classified as undisturbed, based on the presence or absence of human-induced alterations such as roadways, ditching, excavating, and nutrient enrichment (fig. 14). Undisturbed wetlands were located in relatively pristine environments, usually within Acadia National Park, that did not have any of the above activities in or near them. 

and Examples

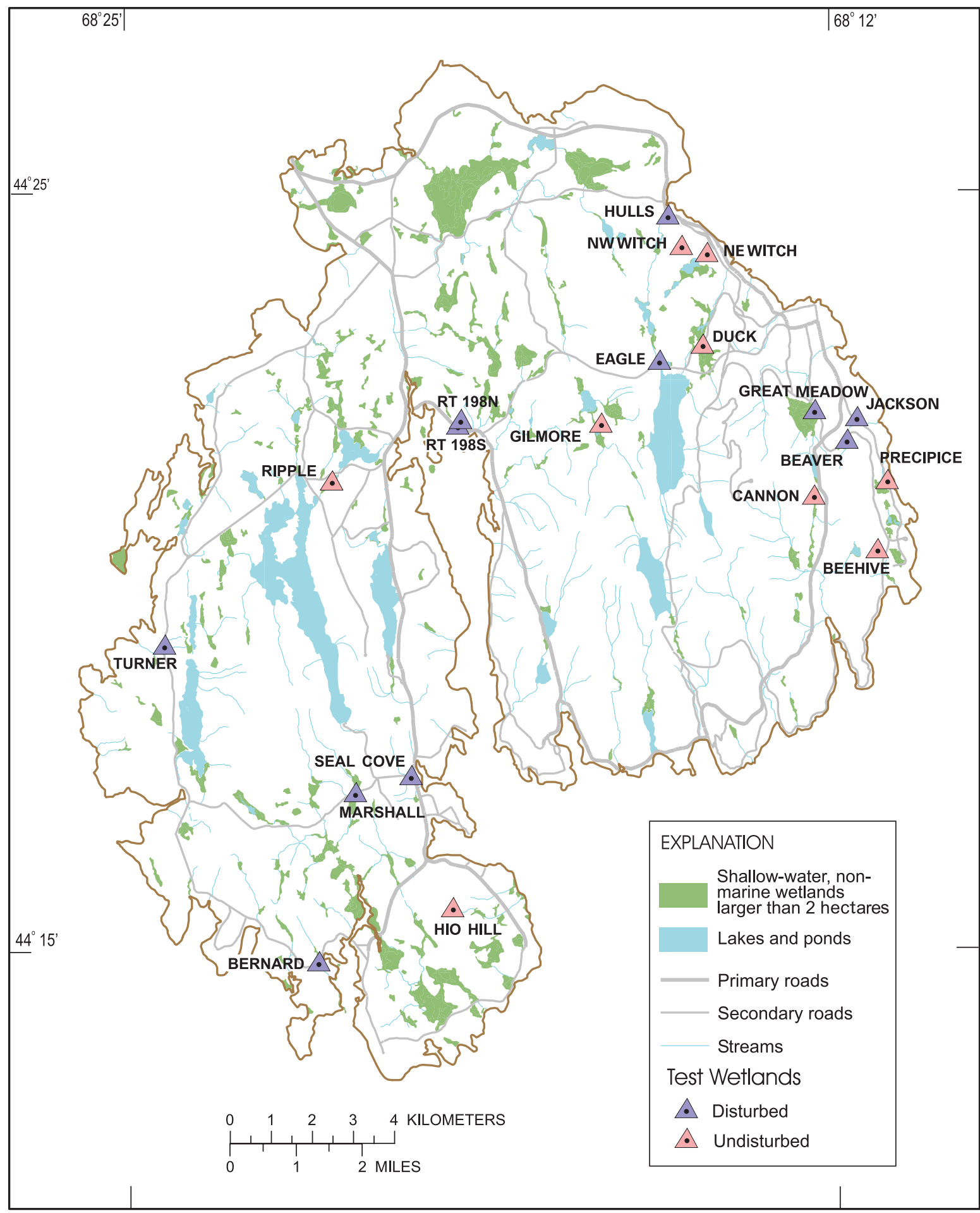

Base from U. S. Geological Survey Digital line graph Bass Harbor, Bar Harbor

Bartlett Island, Seal Harbor, Salsbury Cove, and Southwest Harbor, Maine, 1:24,000

quadrangles. Wetlands from U.S. Fish and Wildlife Service National Wetlands Inventory.

Figure 14. Locations of wetlands greater than 2 hectares and wetland sites for test classificaiton, Mt. Desert Island, Maine. 


\section{Data Collection for the Test Wetlands}

Each of the 20 wetlands was instrumented with 3 piezometers and 1 staff gage. The $3.2 \mathrm{~cm}(1.25-\mathrm{in}$.) diameter piezometers had approximately $0.6-\mathrm{m}(2-\mathrm{ft})$ screens. The bottoms of the screened interval averaged $1 \mathrm{~m}$ below the sediment surface. The piezometers were arranged in a transect across the wetland. The placement of the piezometers was intended to capture the center and edges of the wetland. The piezometers were installed using a 5-cm (2-in.) hand auger, and the annular space was backfilled with sand around the screen and bentonite pellets above the screen. The staff gage was installed in standing water in the deepest part of each wetland. Water levels in the piezometers and at the staff gage were measured weekly during the summer (mid-June through the end of August). The datum for both the piezometers and staff gage measurements was the local land surface. The relative altitudes of the piezometers and staff gages were not surveyed. Water-level data for the summer of 2000 and the summer of 2001 were plotted for each wetland.

Locations for each wetland were determined using a global positioning system (GPS) unit, and the GPS locations were converted to a GIS coverage of the wetlands. This GIS coverage was overlain on a digital version of the 7.5-minute USGS quadrangle map and over coverages of soil type and surficial geology. Soil type was mapped in 1986 at a scale of 1:20,000 by the Natural Resources Conservation Service (NRCS) (Jordan, 1998), and a digital version of these data was obtained from the Orono, Maine NRCS office. Surficial geology was mapped at 1:50,000 (Gilman and others, 1988), and a digital version of these data was obtained from the National Park Service.

\section{Hydrogeomorphic Classification without Hydroperiod Data}

The dichotomous key developed for the HGM subclasses for Mt. Desert Island was used to classify the test wetlands. Preliminary HGM classifications for each of the 20 wetlands were assigned using the dichotomous key based on available GIS coverages (NWI maps, hydrography, soils and surficial geology, and a 10-m resolution digital elevation model) and the 7.5-minute USGS quadrangle map. The set of questions in the key was addressed for each wetland to determine the appropriate subclass. Most of the 20 wetlands were classified easily. A few presented situations where the small size of the wetland presented more than one possible classification of that wetland, because of the difficulty of interpreting geomorphic setting in small wetlands using 1:24,000-scale data. Answers to the key questions and individual classifications of all 20 wetlands are presented in table 4 .

Small wetlands not appearing on NWI maps or wetlands created or modified by human disturbances, such as roads, are difficult to classify using this method. Small wetlands that exist because of ponding behind road berms are particularly difficult to fit into the HGM classification, because the landscape position overall has less to do with their existence than do small perturbations in the landscape that are not discernible on a 7.5-minute USGS quadrangle map.

Another difficulty concerns the relative role that small ponds play in the wetland. In cases where the water is less than $2 \mathrm{~m}$ deep, the pond constitutes the wetland and should not be classified as lacustrine fringe. This is difficult to discern from a topographic map without visiting the location.

\section{Evaluation of Preliminary Hydrogeomorphic Classification Using Hydroperiod Data}

The hydroperiod data for each wetland were compared to the expected hydroperiod characteristics of the wetland subclass to which each was preliminarily assigned (table 3 ). The local precipitation record from the National Weather Service weather station was also graphed for the same period (summer of 2000 and 2001) and compared to the water-level data. If the actual hydroperiod data matched the expected hydroperiod pattern, it was assumed that the preliminary HGM classification assigned using the key was appropriate. Because this involves some judgment, the test is somewhat subjective, but is done using basic hydrogeologic principles. The locations of the staff gage and wells were examined from site sketch maps with respect to the local topography and water-flow directions as estimated from the topographic map (water-flow directions were not determined in the field). The amount and duration of standing water, overall water-level changes during the summer, and rates of water-level change relative to precipitation events were examined for each wetland for both years of data collection. Although the data were not collected for the purpose of verifying a particular classification, they were of sufficient quality for the purpose of this exercise. Horizontal and vertical gradients could not be quantified, however, because the wells were not surveyed with respect to a common datum.

The hydroperiod data were consistent with the preliminary HGM classification for all but 3 of the 20 wetlands. The HGM subclass types assigned to these wetlands included Riverine-Upper Perennial, Lacustrine Fringe, Depressional-Closed, Depressional-Open, DepressionalSemiclosed, Slope, and Organic Soil Flat. Hydroperiod data for typical examples of some of these wetlands are shown in figure 15.

The three wetlands with hydroperiod characteristics that deviated significantly from the expected were Marshall, Seal Cove, and Precipice (see fig. 14 for locations). Marshall and Seal Cove were identified as disturbed wetlands, and the disturbances may have had enough of a hydrologic component to significantly affect the water levels. Precipice (the only undisturbed wetland not to fit the preliminary classification) was assigned as Organic Soil Flat based partly on the soils 


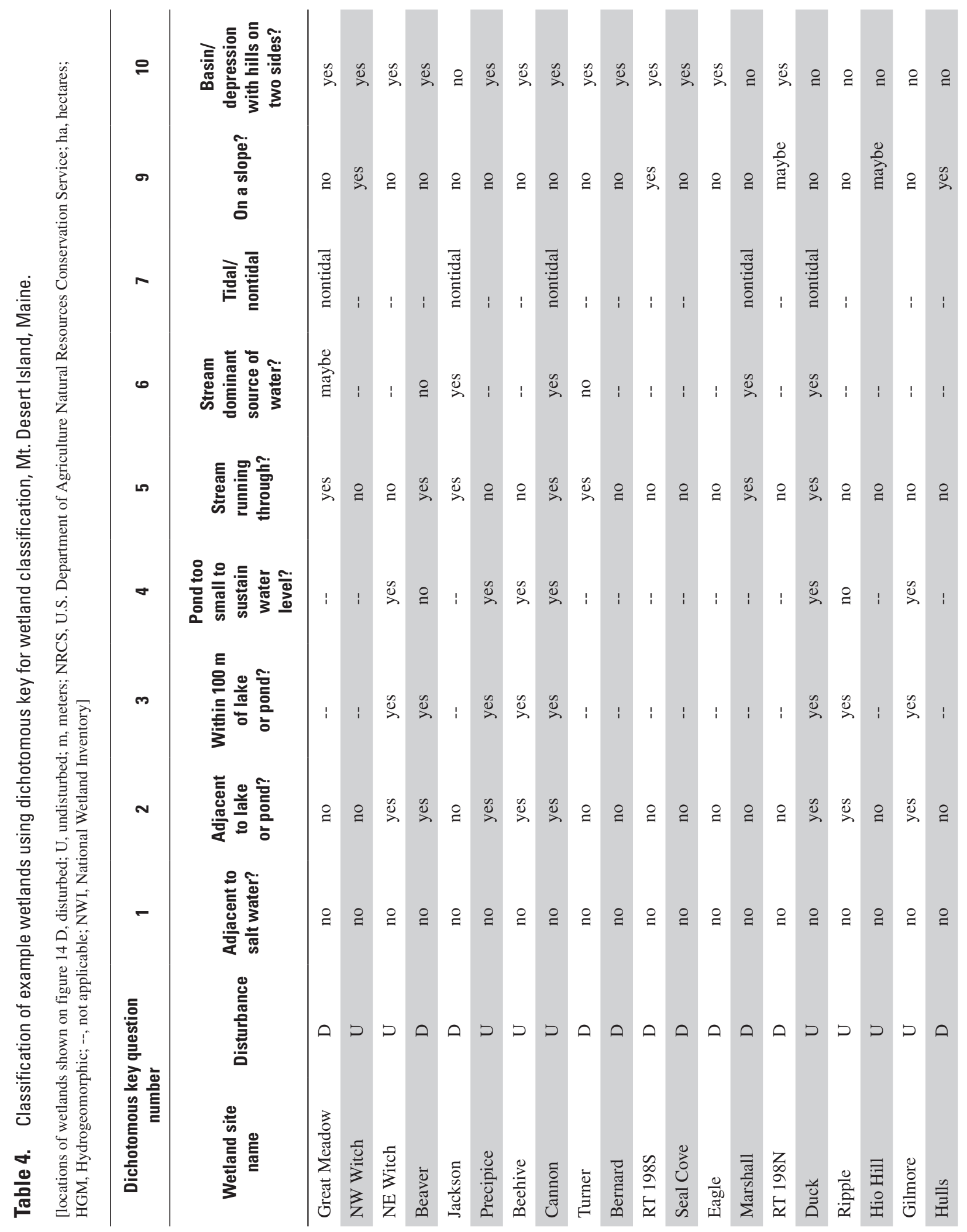




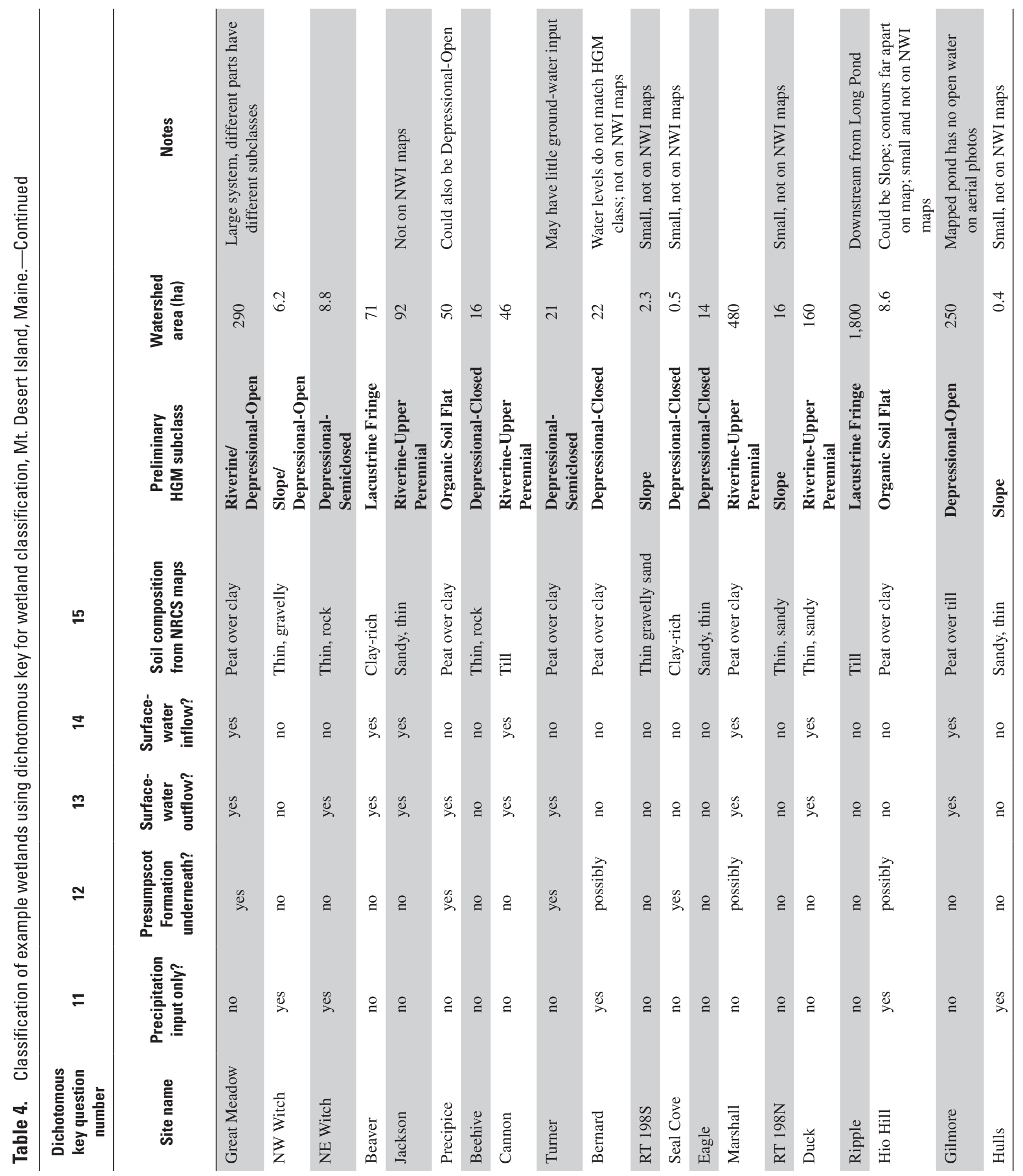


BEEHIVE, 2000

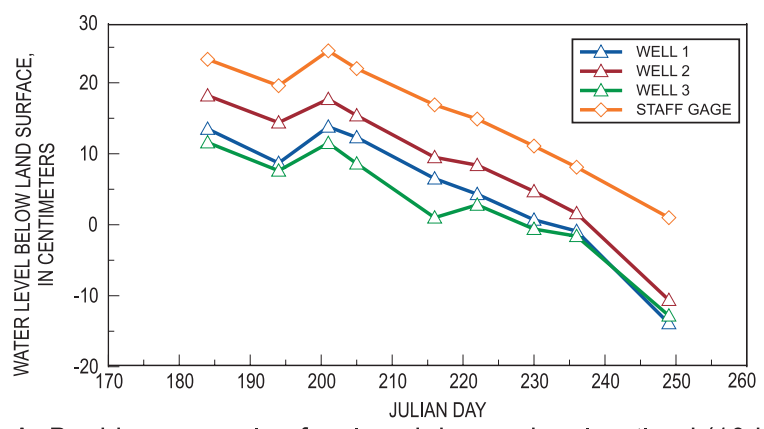

BEEHIVE, 2001

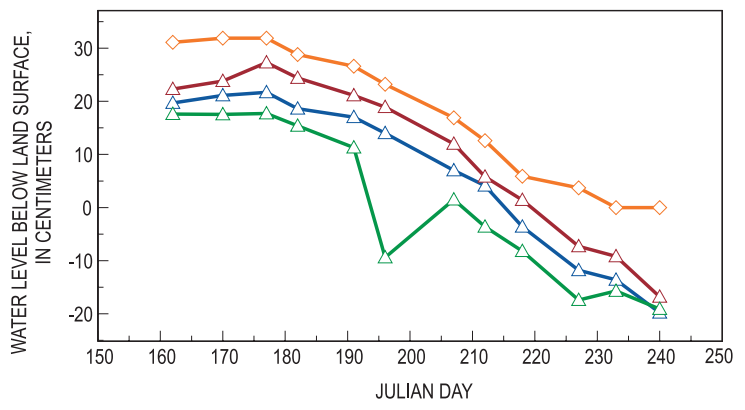

A. Beehive, example of a closed depressional wetland (16-hectare watershed).
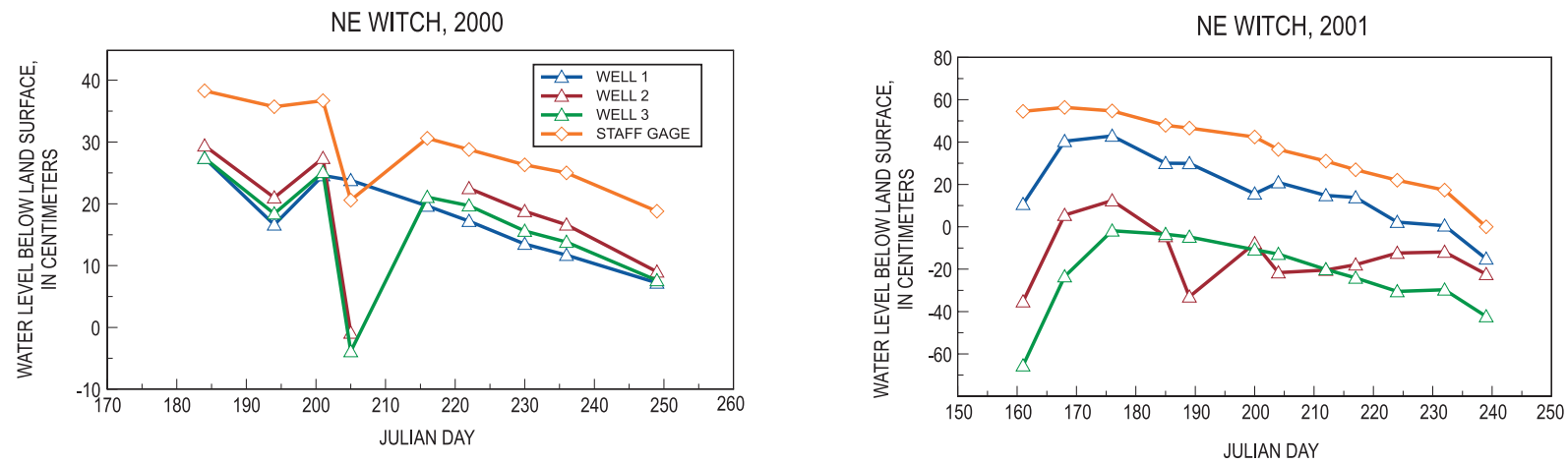

B. NE Witch, example of a semiclosed depressional wetland (8.8-hectare watershed).
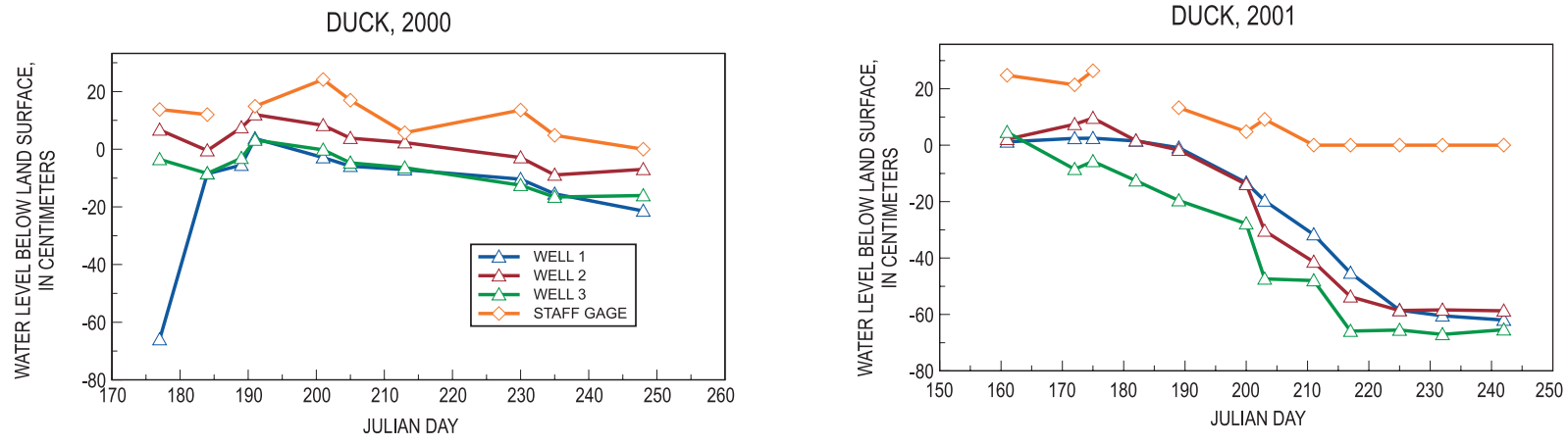

C. Duck, example of an upper perennial riverine wetland (160-hectare watershed).

DAILY PRECIPITATION, 2000

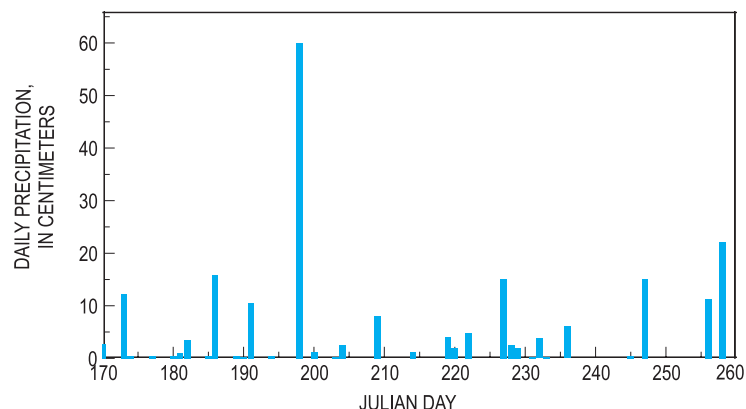

DAILY PRECIPITATION, 2001

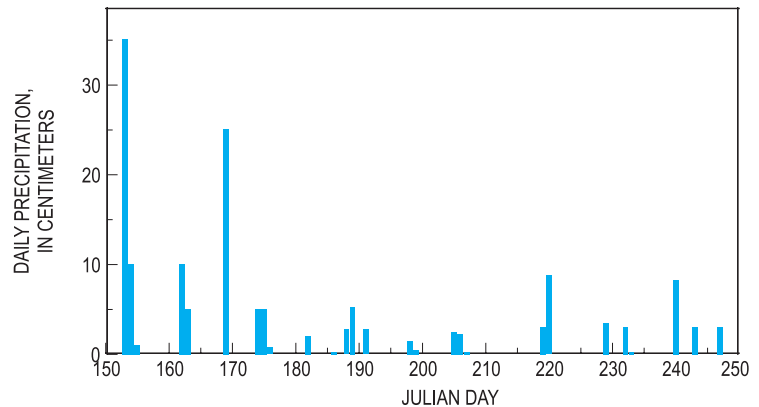

D. Precipitation recorded on Mt. Desert Island National Weather Service station (located on McFarland Hill, Bar Harbor, Maine).

Figure 15. Example hydroperiod data for selected wetland subclasses: A. closed depressional wetland, B. semiclosed depressional wetland, C. upper perennial riverine wetland, and D. precipitation record for wetland data-collection period. Locations of wetlands are shown on figure 14. 
map showing organic soils in that area. Water levels were not expected to change rapidly because of the porosity of peat, but the observed water levels did change relatively rapidly. During the installation of the piezometers, a thin peat layer with clay soils beneath was noted. This may justify changing the wetland classification to Mineral Soil Flat, which would match the observed hydroperiod data better. Seal Cove was a difficult site to classify because it is small. Therefore, neither the wetland nor some local geomorphic features appear on either the NWI maps or the 1:24,000-scale maps. Field observations showed a road berm on the downstream side. It was originally assumed that the berm would act like a dam, and on this basis, the wetland was classified as a closed depression. However, the hydroperiod data show behavior much more like a slope wetland, with little standing water and water levels in the wells below land surface much of the time. The road berm does not appear to prohibit water movement out of the wetland, and it should therefore be assigned the "Slope" subclass. Marshall was assigned to a "Riverine-Upper Perennial" subclass, although the water-level data are more characteristic of a Lacustrine Fringe. In fact, the water levels continued to rise over the course of both summers, possibly indicating a downstream flow restriction and ponding of water. This is likely due to the large wetland size in the Marshall Brook area, and the possibility of beaver activity downstream (field observations indicate an old beaver dam close to the piezometers). In this case, a "beaver activity" modifier could be added to the HGM subclass.

\section{Comparison of Disturbed and Undisturbed Wetlands}

Overall, the test exercise of assigning preliminary HGM subclasses to wetlands using data only available on maps and GIS coverages was successful. Eighty-eight percent of undisturbed wetlands and 82 percent of the disturbed wetlands were assigned preliminary subclasses consistent with the hydrologic field data. After analyzing the hydrologic field data, two of the wetlands were re-assigned to different classes (Precipice and Seal Cove). Although the data from Marshall are not typical for most riverine wetlands, they are consistent with a beaver-dammed riverine system with a large upstream watershed area and large overall wetland area. Hydrologic disturbances (anthropogenic or potentially beaver-caused) do affect the degree to which wetlands can be successfully classified using this method. When the classification is applied to all the wetlands on the island greater than 1 ha in size, it must be understood that the classification is preliminary in nature. Wetlands with significant hydrologic disturbances are less likely to be correctly classified than unaltered, pristine wetlands.

\section{Summary and Conclusions}

A preliminary classification system for wetlands on Mt. Desert Island (MDI), Maine, was developed by the U.S. Geological Survey using a modified hydrogeomorphic (HGM) classification approach, in cooperation with the National Park Service. Twelve wetland subclasses were developed, based on landscape position, surficial geology and soils, and probable sources of water. The twelve HGM subclasses identified for MDI are Riverine-Upper Perennial, Riverine-Nonperennial, Riverine-Tidal, Depressional-Closed, DepressionalSemiclosed, Depressional-Open, Depressional-No GroundWater Input, Mineral Soil Flat, Organic Soil Flat, Tidal Fringe, Lacustrine Fringe, and Slope. The expected overall hydroperiod characteristics of each subclass were predicted using basic hydrogeologic principles, but specific hydroperiod characteristics were not used in the preliminary classification method. The expected hydroperiod characteristics of each subclass provide initial insight into likely wetland functions associated with hydrologic regime. They also can be used as an aide to refining a preliminary HGM classification. The classification system is intended to be used to conduct an initial assessment of wetlands on MDI, using geographic information system (GIS) coverages as an aid to quickly classify the wetlands, without the expense and time of collecting field hydrologic data on each individual wetland. Because this classification is intended to be an initial one, refinements to the subclass assignments could be made after field investigation of any individual wetland. Refinements to the HGM classification system itself also could be made after more hydrologic data on the specific sources and sinks of water for wetlands on MDI were collected and analyzed. This wetland classification system could be applied to other hydrogeologically similar areas of northern New England.

The landscape positions of wetlands on MDI were used in conjunction with previously developed HGM classes to develop the preliminary classification-wetlands adjacent to large open-water lakes and ponds; wetlands adjacent to streams or estuaries and at the same elevation; wetlands in topographic depressions, which include closed depressions, semiclosed depressions with streams leaving them, or open depressions with streams both entering and leaving them; wetlands on wide, flat areas with relatively little topographic relief in the surrounding watershed; and wetlands on slopes. Soil and (or) surficial geological factors considered in the classification are whether the wetland is underlain by mineral soils or thick, organic soils; and whether the Presumpscot Formation underlies the wetland. The sources of water considered for the classification include precipitation, overland flow, overbank flow/lateral exchange with lakes, lateral exchange with streams, ground water, stream inflows, and lateral exchange with estuaries or other saltwater bodies. 

and Examples

The preliminary HGM classification of 20 wetlands using the method developed for MDI was tested by comparing predicted hydroperiod characteristics to field-collected data. Eleven disturbed and nine undisturbed wetlands on the island were recently monitored in a related study that examined a suite of monitoring variables for use in a wetland monitoring strategy for Acadia National Park. Using a dichotomous key and soils, surficial geology, hydrography, and topography data compiled in a GIS, a preliminary HGM classification was assigned to each of the 20 test wetlands. Field hydroperiod data collected in 2000 and 2001 at these 20 wetlands were then compared to the expected hydroperiod characteristics for the preliminary HGM class assigned to each wetland. The actual hydroperiod data agreed with the expected hydroperiod characteristics in 8 of the 9 undisturbed wetlands ( 88 percent) and in 9 of the 11 disturbed wetlands (82 percent). Human activity in and near wetlands, including road building, ditching, and excavating, creates hydrologic changes in disturbed wetlands that may not be readily apparent at the scales of 1:24,000 maps and similarly scaled environmental coverages.

The presence of beavers in the landscape presents a challenge to this method of classification. Although not distinguishable at the map scale, beaver activity can exert a significant effect on the hydrology of wetlands they inhabit. Their effect is often transient because beavers come and go from place to place. A "beaver activity" modifier may be added to the preliminary HGM classification once beaver locations are known.

\section{Acknowledgments}

We thank Amanda Little, Megan Gahl, Anna Kettell, Christie Peshka, and Lisabeth Willey for their assistance in collecting the hydroperiod data. We also thank David Manski and the rest of the Natural Resources staff at Acadia National Park for their logistical support.

\section{References}

Adamus, P.R., Clairain, E.J., Smith, R.D,, and Young, R.E., 1987, Wetland evaluation technique (WET), volume II-Methodology: Vicksburg, Miss., U.S. Army Corps of Engineers Waterways Experiment Station, 206 p.

Brinson, M.M., 1993, A hydrogeomorphic classification for wetlands: Vicksburg, Miss., U.S. Army Corps of Engineers, Waterways Experiment Station, Technical Report WRP-DE-4, $79 \mathrm{p}$.
Calhoun, A.K., Cormier, J., Owen, R., O'Connell, A., Roman. C., and Tiner, R., 1994, The wetlands of Acadia National Park and vicinity: Orono, Maine, Maine Agricultural and Forest Experiment Station, University of Maine at Orono, Miscellaneous Publication no. 721, 99 p., 3 appendixes.

Cole, C.A., Brooks, R.P., and Wardrop, D.H., 1997, Wetland hydrology as a function of hydrogeomorphic (HGM) subclass: Wetlands, v. 17, no. 4, p. 456-467.

Cole, C.A., and Brooks, R.P., 2000, Patterns of wetland hydrology in the ridge and valley province, Pennsylvania: Wetlands, v. 20, no. 3, p. 438-447.

Cowardin, L.M., Carter, V., Golet, F., and LaRoe, E., 1979, Classification of wetlands and deepwater habitats of the United States: Washington, D.C., U. S. Fish and Wildlife Service publication FWS/OBS-79/31,103 p.

Fretwell, J.D., Williams, J.S., and Redman, P.J., compilers, 1996, National water summary on wetland resources: U.S. Geological Survey Water-Supply Paper 2425, 431 p.

Gerla, P.J., 1999, Estimating the ground-water contribution in wetlands using modeling and digital terrain analysis: Wetlands, v. 19 , no. 2 , p. 394-402.

Gilman, R.A., Chapman, C.A., Lowell, T.V., and Borns, H.W., Jr., 1988, The geology of Mt. Desert Island, A visitor's guide to the geology of Acadia National Park: Maine Geological Survey Bulletin 38, 50 p., 2 pls.

Green, M.C., 1991, Modeling wetland groundwater flow and predicting hydrologic response to management alternatives at Summerton Bog, Oxford, Wisconsin: University of Wisconsin-Madison Master's Thesis, 123 p., 5 appendixes.

Gwin, S.E., Kentula, M.E., and Schaffer, P.W., 1999, Evaluating the effects of wetland regulation through hydrogeomorphic classification and landscape profiles: Wetlands, v. 19 , no. 3, p. 477-489.

Jordan, G.B., 1998, Soil survey of Hancock County area, Maine: U.S. Department of Agriculture, Natural Resources Conservation Service, 278 p., 103 map sheets.

Kahl, J. S., Manski, D., Flora, M., and Houtman, N., 2000, Water resources management plan, Acadia National Park: Bar Harbor, Maine, National Park Service, NPS D-209, April 2000, 5 chap., variably paginated.

Lent, R.M., Weiskel, P.K., Lyford, F.P., and Armstrong, D.S., 1997, Hydrologic indices for nontidal wetlands: Society of Wetland Scientists, Wetlands, v. 17, no. 1, p. 19-30. 
Lowell, T.V., 1989, Late Wisconsin glacial geology of the eastern portion of Mt. Desert Island, in Tucker, R.D., and Marvinney, R.G., eds., 1989, Studies in Maine Geology, v. 6-Quaternary Geology: Augusta, Maine, Maine Geological Survey, p. 103-118.

Lubinski, Susan, Hop, Kevin, and Gawler, Susan, 2003, U.S. Geological Survey-National Park Service vegetation mapping program, Acadia National Park, Maine, project report: U.S. Geological Survey Upper Midwest Environmental Sciences Center and Maine Department of Conservation National Areas Program, Revised Edition October 2003, 50 p., 9 appendixes.

Mitsch, W.J., and Gosselink, J.G., 2000, Wetlands (3d ed.): New York, N.Y., John Wiley and Sons, 920 p.

National Oceanic and Atmospheric Administration, 2002, Monthly station normals of temperature, precipitation, and heating and cooling degree days, 1971-2000, Maine: Asheville, N.C., NOAA National Climate Data Center, Climatography of the United States no. 81, 16 p.

Nielsen, M.G., 2002a, Water budget for and nitrogen loads to Northeast Creek, Bar Harbor, Maine: U.S. Geological Survey Water-Resources Investigations Report 02-4000, $32 \mathrm{p}$.

Nielsen, M.G., 2002b, Estimated quantity of water in fractured bedrock units on Mt. Desert Island, and estimated groundwater use, recharge, and dilution of nitrogen in septic waste in the Bar Harbor area, Maine: U.S. Geological Survey Open-File Report 02-435, 45 p.

Nielsen, M.G., Caldwell, J.M., Culbertson, C.W., and Handley, Michael, 2002, Hydrologic data collected in small watersheds on Mt. Desert Island, Maine, 1999-2000: U.S. Geological Survey Open-File Report 02-416, 47 p.

Novitzki, R.P., 1982, Hydrology of Wisconsin wetlands: U.S. Geological Survey Information Circular 40, 22 p.

O’Brien, A.L., and Motts, W.S., 1980, Hydrogeologic evaluation of wetland basins for land use planning: Water Resources Bulletin v. 16, p. 785-789.
Rheinhardt, R.D., Brinson, M.M., and Farley, P.M., 1997, Applying wetland reference data to functional assessment, mitigation, and restoration: Wetlands, v. 17 , no. 2 , p. 195-215.

Schaffer, P.W., Kentula, M.E., and Gwin, S.E., 1999, Characterization of wetland hydrology using hydrogeomorphic classification: Wetlands, v. 19, no. 3, p. 490-504.

Smith, R.D., Ammann, A., Cartoldus, C., and Brinson, M.M., 1995, An approach for assessing wetland functions using hydrogeomorphic classification, reference wetlands, and functional indices: Washington, D.C., U.S. Army Corps of Engineers Wetlands Research Program, Technical Report WRP-DE-9, 71 p., 5 appendixes.

Smith, G.W., 1985, Chronology of Late Wisconsinan deglaciation of coastal Maine, in Borns, H.W., Jr., LaSalle, P., and Thompson, W.B., eds., 1985, Late Pleistocene history of northeastern New England and adjacent Quebec: Geological Society of America Special Paper 197, Boulder, Colo., Geological Society of America, p. 29-44.

Tiner, R.W., 2002, Enhancing wetlands inventory data for watershed-based wetland characterizations and preliminary assessments of wetland functions, in Tiner, R.W., ed., 2002, Watershed-based wetland planning and evaluation-A collection of papers from the Wetland Millennium Event, Quebec City, Canada: Berne, N.Y., Association of State Wetland Managers, Inc., p. 17-39.

U.S. Bureau of the Census, 2001, 2000 census of population and housing-Population and unit counts, Maine: U.S. Department of Commerce, Bureau of the Census, 2001.

U.S. Fish and Wildlife Service, 1998, National Wetlands Inventory Maps, vector digital data from Maine Office of Geographic Information Systems, scale 1:24,000, accessed on January 3, 2000, at http://megis.maine.gov/ catalog/. 
